\title{
A DÉL-DUNÁNTÚL TERÜLETFEJLESZTÉSI KONCEPCIÓJÁNAK ALAPELEMEI
}

\author{
(Elements of the South Transdanubian regional development concept) \\ FARAGÓ LÁSZLÓ - HORVÁTH GYULA
}

\section{A területfejlesztési koncepció elkészitésének előzményei}

A Dél-Dunántúl fejletlenebb és több gonddal küzd, mint a központi és az északdunántúli régió, de a válság nem annyira mély, mint Északkelet-Magyarországon. Ezért itt szükség van egy átfogó programra, miáltal a várható eredmény is kedvezőbb lehet, mint a mélyebb válságba került régióban. Ugyanakkor nyilvánvaló, hogy csak összefogáson alapuló szándék, megfelelö intézmények és a szükséges források megléte esetén van esély jelentősebb eredményre.

A programkészítés és megvalósítás biztató előjele volt, hogy a régió különbözö szereplöi nem csak az állam segítségétöl várták a kibontakozást, hanem maguk is tenni akartak a változásokért. Már a kezdeti lépéseknél sikerült a régió számos szereplöjét bevonni a program elökészítésébe. Maga a koncepció készítésének folyamata is igen jelentősnek bizonyult a fejlödéshez szulkséges térségi integrálódás tekintetében. A tervezési folyamat gyakran az érdekérvényesités keretéull is szolgált.

A program sikerét megelölegező további jel volt, hogy több különböző szintú és típusú szervezet járult hozzá információval, közremủködéssel vagy nem utolsó sorban anyagiakkal is a megvalósításhoz.

A koncepció készítésével párhuzamosan a regionális középszint hiányában jött létre a Dél-Dunántúli Regionális Fejlesztési Alapítvány, amelyet Baranya, Somogy, Tolna és Zala megye alapitott. E közalapítvány, amelynek kuratóriumában a kormányzati képviselökön kívül a régió önkormányzatai, politikusai, egyetemei, tudományos és gazdálkodó szervezetei is képviseltetik magukat, közvetlen előzménye lehet a jelenleg egyeztetés alatt lévő területfejlesztési törvénytervezetben javasolt regionális területfejlesztési tanácsnak.

A biztató elözmények láttán határozta el a kormány, hogy az „Alföld fejlesztési koncepcióját" követően a Dél-Dunántúl lesz a második nagyrégió, amelyre fejlesztési koncepciót készít. A Dél-Dunántúl területfejlesztési koncepciója bekerült az 1994-es kormányprogramba. E feladatot külön nevesítve nem erỏsítette meg az új kormány. A feladatért felelős Környezetvédelmi és Területfejlesztési Minisztérium a tervezésre fordít- 
Faragó László - Horváth Gyula: A Dél-Dunántúl területfejlesztési koncepciójának alapelemei.

Tér és Társadalom, 9. 1995. 3-4. 47-77. $p$

ható szükös forrásaiból az elözetes vizsgálatok alapján egy gazdaság-orientált koncepció elkészitését rendelte meg a MTA Regionális Kutatások Központjától. A koncepció és a „Kormány elöterjesztés tervezete” még 1994 nyarán elkészült, de mind a mai napig nem került a kormány elé. Központi szinten a program megvalósításáert azóta nem tettek lépéseket .

\section{A Dél-Dunántúl általános helyzete}

A Dél-Dunántúl - noha fejlődésében ma még nem mutatkoznak olyan mély válságjelek, mint az ország keleti, északkeleti régióiban - gyenge gazdasági szerkezeti elemekkel rendelkezik, még ha ezek stabilizálódnak is, perspektivikusan a régió eröteljesen leszakad a magterületekről és az ország bizonytalan sorsú válságtérségévé válhat.

1) A magas agrárfoglalkoztatotti arány és a tercier szektor alacsony súlya az elmaradottság tipikus fokmérője. A mediterrán perifériáktól (ahol a 25-50\%-os arány sem ritka) a Dél-Dunántúl az iparosodottság magasabb fokában különbözik. A tercier ágazat súlya a közös piaci elmaradott térségek többségében a dél-dunántúli átlag alatti ( 1 . ábra).

A tercier szektor belső szerkezete azonban a Dél-Dunántúlon még magán viseli az irányitott piacgazdaság sajátosságait. A piaci szolgáltatásokban (ezen belül is a termelő és a pénzügyi ágazatokban) alacsony a foglalkoztatottak aránya. Ez egyben azt is jelzi, hogy a régió foglalkozási szerkezetére ezeknek az ágazatoknak a fejlesztése lehet meghatározó befolyással, illetve, hogy ezek a tevékenységek a gazdasági átrendeződésben is fontos szerepet játszhatnak. A piacgazdaság szakemberszükségletének és technológiaitechnikai átalakulásában fontos hajtóerőt jelentő felsőoktatási és $\mathrm{K}+\mathrm{F}$ ágazat elmaradottsága igen nagy mértékú.

Magas a közös piaci átlagtól való eltérés a munkanélküliségi mutató esetében is. Noha a régió értéke a magyar átlag alatt van, a nyugat-európai átlagot 30\%-kal meghaladja.

2) A Dél-Dunántúl infrastrukturális mutatói nemzetközi összehasonlításban a hazainál is kedvezötlenebb képet mutatnak. Csupán a vasúthálózat-sürüség és az orvosok fajlagos száma haladja meg a közös piaci átlagokat. Különösen fejletlen a régió minöségi közúti közlekedési hálózata és a telefonhálózat. Ahhoz, hogy például a régió közúthálózata az európai átlagnormáknak megfeleljen, kb. $200 \mathrm{~km}$ autópályát, $1000 \mathrm{~km}$ elsörendú foútvonalat kellene építeni, a nyugat-európai telefonellátottsági szint eléréséhez pedig 440 ezer új telefon fövonalra lenne szükség. A közlekedési-hírközlési mutatókat tekintve a Dél-Dunántúl egyértelmüen a fejletlen mediterrán perifériák szintjén áll, bár a hírkőzlésben a spanyol és a görög régiók már egy évtizede a dél-dunántúli átlagot 2530\%-kal meghaladták, s azóta a különbség természetesen nött. És még nem is említettük a Dél-Dunántúl esetében nem értelmezhetö légi közlekedést. Nyugat-Európában kevés olyan régió van, amelynek ne lenne közforgalmú repülőtere. 
Faragó László - Horváth Gyula: A Dél-Dunántúl területfejlesztési koncepciójának alapelemei. Tér és Társadalom, 9. 1995. 3-4. 47-77. p

TÉT 1995-3-4 A Dél-Dunántúl területfejlesztési koncepciójának alapelemei

3) Mindent egybevetve azt állapítjuk meg, hogy a Dél-Dunántúl a nyugat-európai NUTS 2 régiókkal összehasonlítva sajátos helyzetben van. A gazdaságot jellemző mutatók sorában éppúgy találhatunk a modern gazdaságra utaló kedvező értékeket, mint ahogy szép számmal vannak a megkésett fejlödést bizonyító jelek is. Az indusztriális fejlödési szakasz markáns jegyei (urbanizációs szint, az iparosodottság mértéke, energiafelhasználás) miatt az Európai Unió elmaradott perifériáihoz nem sorolható, de nem illeszthető a posztindusztriális fejlődési pályára lépett régiók sorába sem, a tercier ágazatok és az infrastruktúra fejletlensége miatt. Leginkább a két fejlödési szakasz határán álló, az átalakulás keresztútjához érkezett európai vidékekhez hasonlítható, amelyek közül több északkelet-olaszországi, dél-francia, portugál és dél-német régió megfelelö válaszokat fogalmazott meg az európai kihívásokra.

4) A régió általános helyzetképe az azt alkotó megyék különbözősége miatt árnyalt. A régió négy eltérö, sajátos gazdasági karakterü megyéből áll, amelyek a különbözö gazdasági jelzőszámok alapján eltérő helyre kerülnek mind egymáshoz, mind az ország többi megyéjéhez képest. A megyéken belüli kistérségeket vizsgálva az eltérések még szembetűnőbbek. A régió 28 kistérsége közül, a gazdasági fejlettségi mutatót tekintve, csupán 9 múlja felül az országos átlagot (1. táblázat).

\section{A régió nemzetközi versenyképességét befolyásoló tényezők}

1) A régió gazdaságának exportképessége gyenge, 1993-ban az ország exportjának csupán 6,5\%-a jutott a Dél-Dunántúlra.

Az export fajlagos mutatói (exportráta, az egy foglalkoztatottra jutó külkereskedelmi értékesítés volumene) az országos átlag alatt vannak, és a 80-as évtizedhez képest a 90es évek legelején csökkenö tendenciát mutatnak vagy növekedési ütemük a legalacsonyabb az országban.

A gyenge exportorientáció ágazati egyenetlenséggel is párosul, a régió vezetô ágazatainak (élelmiszeripar, könnyüipar) exportrátái megyénként lényeges eltérést mutatnak.

Az exportmutatókhoz hasonlóan kedvezötlen képet találunk a vegyes vállalatok körében is. Mind a vegyes vállalatok aránya, mind pedig e vállalatok sürủsége (tízezer lakosra jutó száma) alacsony.

A kedvezőtlen reálfolyamatok mellett a távlati külgazdasági stratégia kidolgozása szempontjából kedvező tényezőket is felfedezhetünk a dél-dunántúli régióban. Figyelemre méltó jellegzetességnek kell tekintenünk, hogy a bruttó exportteljesitmények ágazatcsoportonkénti tagozódása az ország más térségeitől eltérỏ vonásokat mutat. Az ágazati átrendeződés megindulását jelzi, hogy Somogyban az exportforgalom nagyobb hányada $(53,2 \%-a)$, Baranyában pedig jelentős része $(37,4 \%-a)$ az iparon kívüli szektorokban zajlott. 
Faragó László - Horváth Gyula: A Dél-Dunántúl területfejlesztési koncepciójának alapelemei.

Tér és Társadalom, 9. 1995. 3-4. 47-77. p

1. ABRA: A dél-dunántúli régió helye az európai és a magyar gazdasági térben (The place of the South-Transdanubian region in the European and Hungarian economic space)

Népességi adatok az EUR 12 átlag \%-ában

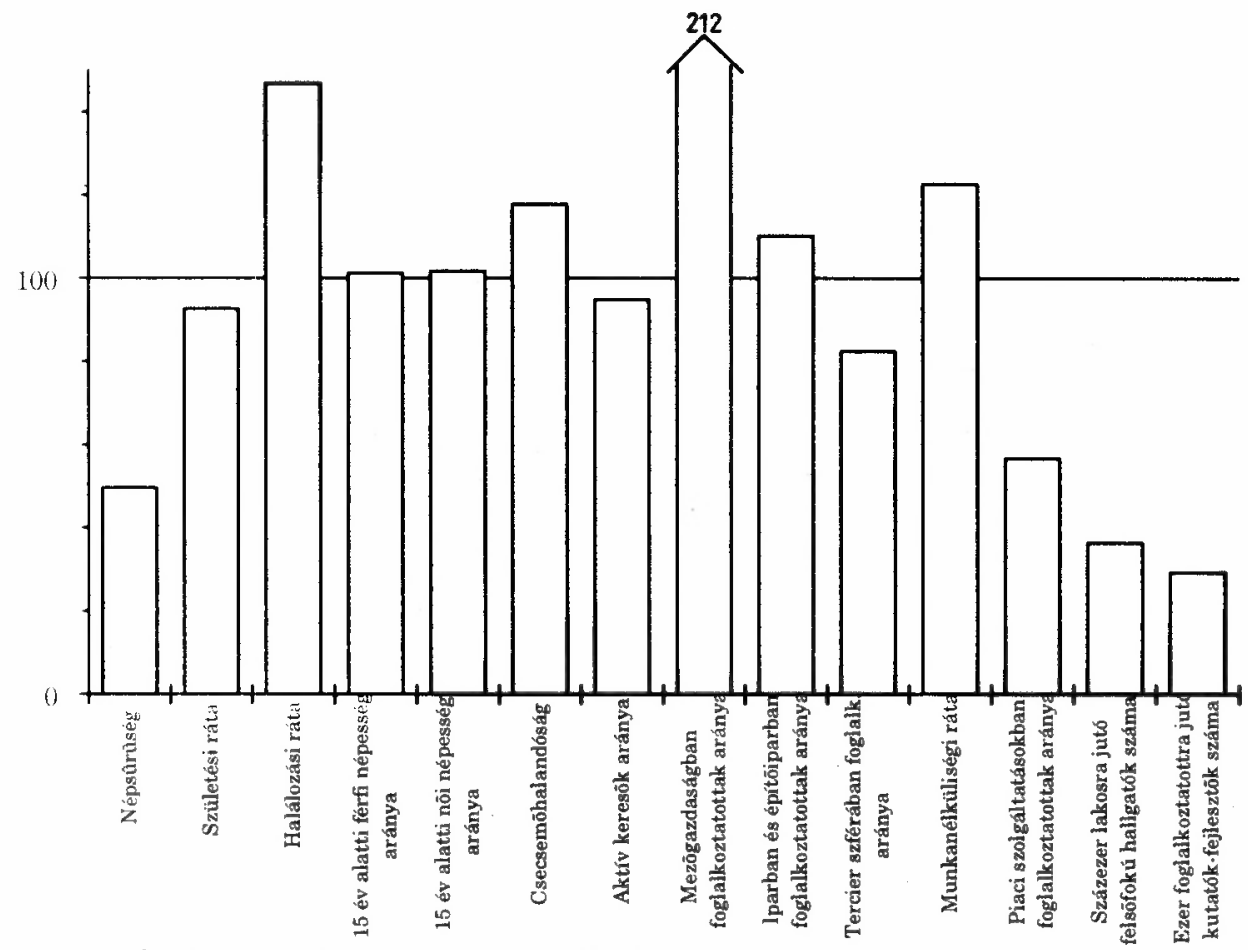

Mezögazdasági adatok az EUR 12 átlag \%-ában

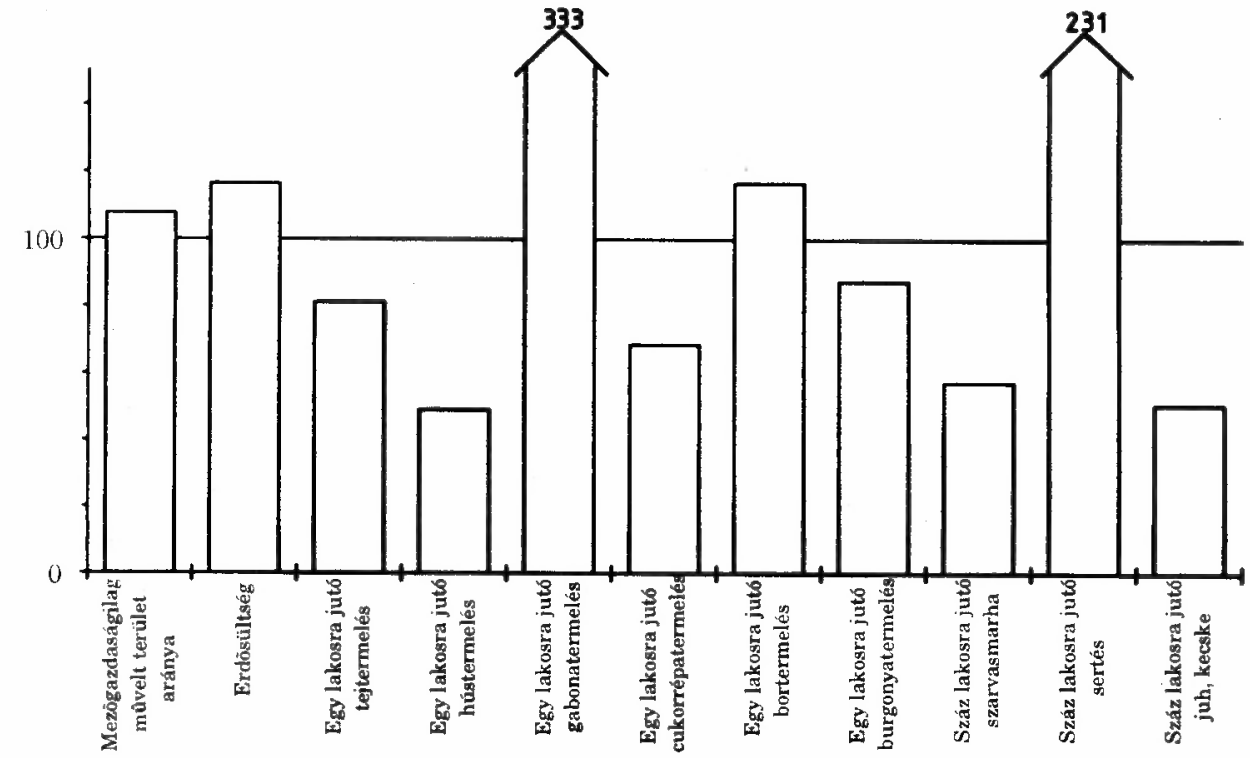


Faragó László - Horváth Gyula: A Dél-Dunántúl területfejlesztési koncepciójának alapelemei. Tér és Társadalom, 9. 1995. 3-4. 47-77. p

Infrastruktúra adatok az EUR 12 átlag \%-ában

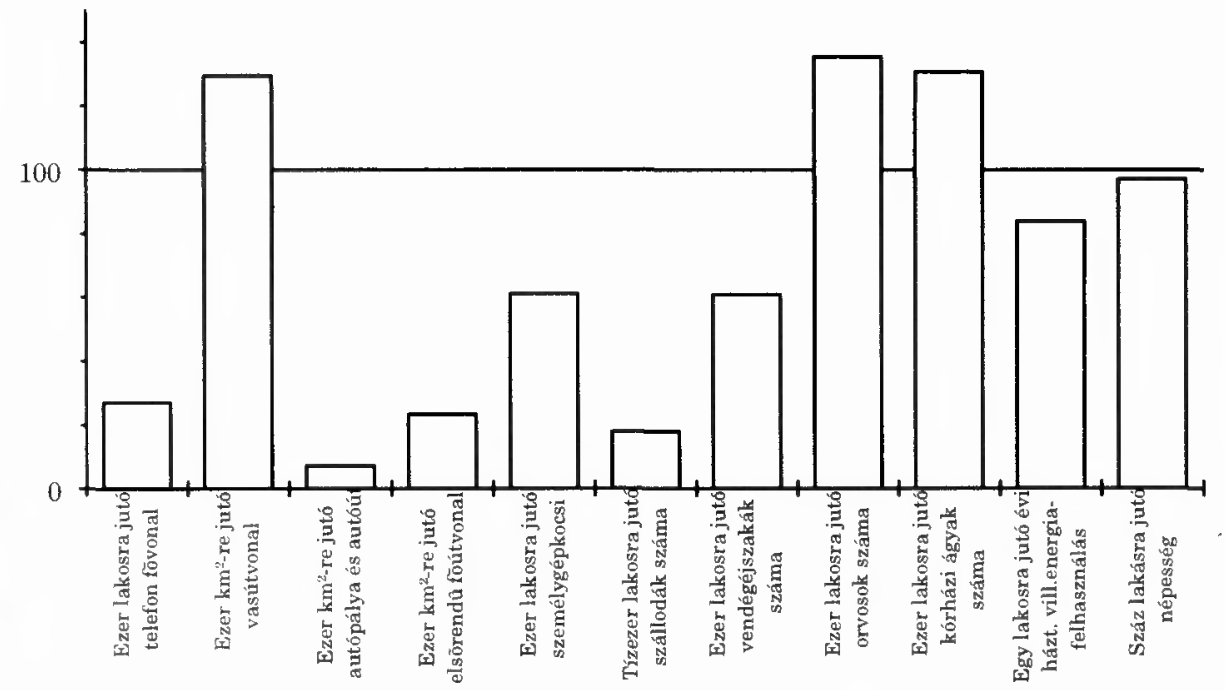

Dél-Dunántúl Magyarország \%-ában

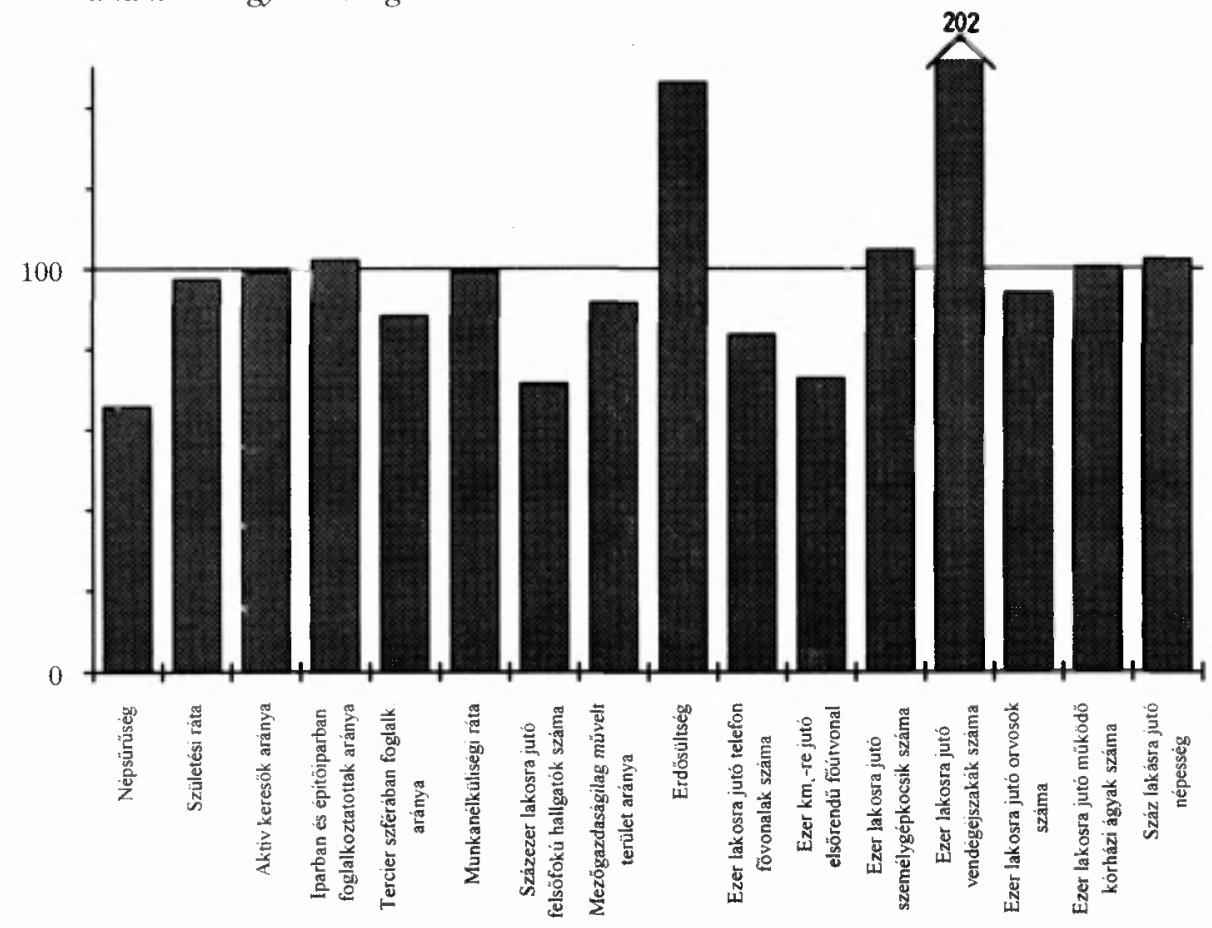




\section{TÁBLÁZAT}

A dél-dunántúli városkörzetek országon és régión belüli poziciója a gazdasági egészség komplex mutatója alapján

(The position of South-Transdanubian urban areas within the country and the region according to three complex measure of the economic health)

\begin{tabular}{|c|c|c|c|}
\hline \multirow[t]{2}{*}{ Az országon belüli } & \multicolumn{3}{|c|}{ A régión belüli pozíció } \\
\hline & Az átlag felett (7) & $A z$ átlag körül (8) & Az átlag alatt (13) \\
\hline \multirow{8}{*}{ Az átlag felett (9) } & Fonyód & & \\
\hline & Siófok & & \\
\hline & Balatonboglár & & \\
\hline & Héviz & & \\
\hline & Pécs & Szekszárd & \\
\hline & Keszthely & Nagykanizsa & \\
\hline & Zalaegerszeg & & \\
\hline & Kaposvár & & \\
\hline \multirow{9}{*}{$\mathrm{A} z$ átlag körül (14) } & & Mohács & \\
\hline & & Sásd & \\
\hline & Bonyhád & Marcali & \\
\hline & Paks & Nagyatád & \\
\hline & Lenti & Barcs & \\
\hline & Koinló & Zalaszentgrót & \\
\hline & Dombóvár & Lengyeltóti & \\
\hline & & Szigetvár & \\
\hline & & Csurgó & \\
\hline \multirow{5}{*}{ Az átlag alatt (5) } & & & Siklós \\
\hline & & & Tab \\
\hline & & & Sellye \\
\hline & & & Tamási \\
\hline & & & Letenye \\
\hline
\end{tabular}


Faragó László - Horváth Gyula: A Dél-Dunántúl területfejlesztési koncepciójának alapelemei. Tér és Társadalom, 9. 1995. 3-4. 47-77. $p$

2) Kedvezötlen képet találunk a vegyes vállalatok körében. Mind a vegyes vállalatok aránya, mind pedig sủrủsége alacsony. Az ország vegyes vállalatainak 7,5\%-a (681) található a Dél-Dunántúlon, a súrüségi mutató nem éri el az országos átlag kétharmadát $(5,18)$. A vegyes vállalatok 18 milliárd 134 millió $\mathrm{Ft}$ alapító vagyonnal rendelkeztek. $\mathrm{Az}$ egy vegyes vállalatra jutó alapítói vagyon az országos átlag fele $(26,6$ millió $\mathrm{Ft})$. A kizárólag külföldi tulajdonú vállalkozások aránya $10,6 \%$, az országos átlag négyötöde.

Az eddig lezajlott privatizáció során 10 milliárd 832 millió Ft külföldi tőke került a Dél-Dunántúlra, a jegyzett össztőke 17,4\%-a. Baranya és Zala megye adja a külföldi befektetések háromnegyedét. A német tőke domináns (57\%-os) pozíciója mellett az osztrák, az olasz és az USA-beli befektetők részesedése jelentős.

3) Távlatilag a nemzetközi integrációban való részvételt kedvezöen befolyásolhatja a régió megyéinek közremüködése $a$ közép-európai regionális együttmüködésekben. $\mathrm{Az}$ Alpok-Adria Munkaközösségben és a Duna Menti Tartományok Munkaközösségében felhalmozott fél évtizedes tapasztalatok, a nemzetközi kapcsolatépítésben megszerzett rutin - koncepciózus programokkal párosulva - előnyös kiinduló feltételei lehetnek a régió európai integrálódásának.

A hatórmenti együttmüködésnek azonban akadályai vannak. Egyrészt a régióval határos Horvátország politikai és gazdasági instabilitása, másrészt a szomszédos területek gazdasági elmaradottsága, a határhoz közeli egyetlen nagyváros, Eszék szerepköre az ország városhierarchiájában beszükült. A hadigazdaság fenntartása, az új horvát és a majdani szlovén megyei közigazgatási rendszer kiépítése, belső gazdasági kapcsolataik fejlesztése, nem utolsó sorban az erősen centralizált állami közigazgatás érezhető félelme az országok területi integritásának megrendülése miatt az intenzív határmenti kooperációkat a távolabbi jövő feladatává teszi. Biztató ugyanakkor, hogy regionális szakértök az északi horvát és szlovén térségek fejlesztésében komoly szerepet szánnak a pannóniai gazdasági erötérhez való kapcsolódásnak.

Szakértöi becslés a dél-dunántúli megyék közép-európai (Alpok-Adria térségi) kötődésében jelentös különbségeket mutatott ki (2. táblázat).

4) A humán infrastruktúra számtalan eleme alkalmas a külgazdaságbarát üzleti légkör fejlesztésére. A régió felsőoktatási intézményeinek többségére kiterjedt nemzetközi kutatási együttmüködések jellemzök. Pécs diplomáciai alcentrummá fejlődése (konzulátusok és tiszteletbeli konzuli tisztségek létesitése) a nemzetközi kapcsolatok szervezésében az egész Dél-Dunántúlra, sőt a délnyugat-alföldi területre is kedvezö hatást gyakorolhat. A régió népességének idegen nyelvtudása országos átlag feletti, közgazdasági felsöoktatási intézményei és átalakuló egyetemei alkalmassá tehetók külkapcsolatokhoz értő szakemberek képzésére, továbbképzésére. Az egyetemeken elszigetelten folyó Európa-kutatások kutatási társulássá szervezhetök, amely szolgáltatásokat is nyújthatna külgazdasági koncepciók összeállitásához. 
Faragó László - Horváth Gyula: A Dél-Dunántúl területfejlesztési koncepciójának alapelemei. Tér és Társadalom, 9. 1995. 3-4. 47-77. $p$

54 Faragó László-Horváth Gyula

TÉT 1995 -3-4

2. TÁBLÁZAT

A dél-dunántúli megyék Alpok-Adria régiókba irányuló kivitele, 1992

(Volume of export of the South-Transdanubian counties into the regions of the

Alps-Adriatic Working Community, 1992)

\begin{tabular}{|l|r|r|r|r|r|}
\hline \multirow{2}{*}{\multicolumn{1}{c|}{ Alpok-Adria }} & \multicolumn{5}{c|}{ Export, millió forint } \\
\cline { 2 - 6 } & Baranya & Somogy & \multicolumn{1}{c|}{ Tolna } & \multicolumn{1}{c|}{ Zala } & Összesen \\
\hline Karintia & 47,0 & 123,3 & 9,0 & 86,7 & 257,0 \\
Burgenland & 19,0 & 22,8 & - & 5,1 & 46,9 \\
Salzburg & - & - & 18,0 & 5,1 & 23,1 \\
Felsö-Ausztria & 601,3 & 205,6 & 630,0 & 91,8 & 1528,7 \\
Stájerország & 226,0 & 365,5 & 270,0 & 362,1 & 1223,6 \\
Bajorország & 441,6 & 530,0 & 45,0 & 331,5 & 1348,1 \\
Veneto & 150,3 & 50,3 & 139,5 & 892,5 & 1232,6 \\
Friuli-Venezia Giulia & 56,4 & 251,3 & - & 15,3 & 323,0 \\
Lombardia & 18,8 & 1407,3 & 157,5 & 20,4 & 1604,0 \\
Szlovénia & - & 4,6 & & 295,8 & 300,4 \\
Horvátország & 49,0 & 67,9 & - & 28,6 & 145,5 \\
\hline Összesen & 1609,4 & 3028,6 & 1269,0 & 2134,9 & 8031,9 \\
\hline Az összes export \%-ában & 10,7 & 31,0 & 16,5 & 18,2 & 18,2 \\
\hline
\end{tabular}

5) A nemzetközi gazdasági kapcsolatok fejlesztését szolgáló piaci intézményrendszer csírái megtalálhatók a régióban. Kiépülöben vannak azok a szervezetek, amelyek a jövőben fontos szervezö és közvetító szerepet játszhatnak a külkapcsolatok alakításában. Formálódóban vannak a megyei kamarai hálózatok, megjelent több külkereskedelmi (értékesitő, marketing, piackutató, szállitmányozó) vállalkozás. A Pécsi Ipari Vásár töıténelmi tradíciói folytán is - a közép-európai vásárhálózat részeként, de a jelenleginél markánsabb koncepcióval - a régió meghatározó bel- és külföldi közvetító intézményévé fejleszthetö, amelyet jól kiegészíthetnek a többi megyeszékhely és egyéb városok regionális és lokális hatókörú árubemutatói. A banki-pénzügyi szolgáltatások általános fejletlensége ellenére pozitiv faktorként értékelendö, hogy két nagy országos szakositott külkereskedelmi banknak - az MKB-nek és az Inter-Európa Banknak - jól müködö fiókjai vannak Pécsett, amelyek - ha kellő döntési kompetenciához jutnának - a külgazdasági kapcsolatok fejlesztésében fontos szervezöi funkciót tölthetnének be. (Ez természetesen nem jelenti azt, hogy nem kell akár új pénzügyi szervezetek, pl. külföldi bankfiókok telepítését fontolóra venni.)

A dél-dunántúli régió nemzetközi munkamegosztásban való részvételének jelenlegi szinvonala, a térség geopolitikai helyzete, tradicionális történelmi kapcsolatai, valamint a kedvező szellemi-infrastrukturális adottságok miatt a gazdaságfejlesztési stratégiában a 
nemzetközi versenyképesség megteremtése, az ezt elösegitő szervezetrendszer fejlesztése domináns tényezőként veendő figyelembe.

6) A Dél-Dunántúl gazdaságának fejlettségi szinvonalát és exportképességét a gazdaság szerkezetén, üzemi struktúráján és az irányitási-alárendeltségi szervezeti viszonyokon kivül a régió innovációs potenciálja, a termelés-elosztás-értékesités technológiai állapota is befolyásolta. A viszonylag későn lezajlott iparositás a térség eröteljes külső függését idézte elö, a vállalati struktúrák és tulajdonviszonyok átalakulását követően a belsö gazdasági szereplök száma ugyan megnött, a termelés- és termékfejlesztés hagyományok hiján - azonban alacsony színvonalú, a gazdaság új szereplöi többnyire „,jogelödjeik” termelési kultúráját folytatják. A termék- és technológiaváltás feltételei a régióban kedvezőtlenek, az elmúlt két-három évben tapasztalt változások arra figyelmeztetnek, hogy fennáll a veszélye annak, hogy újfajta függöség alakul ki a föváros és a régió között: a ,szürö" modell (a filtering-down) tovább müködik, a központi régió lokalizációs elönyeit kihasználva - megszüri a legértékesebb termelési tevékenységeket - a kutatás-fejlesztést, a pénzügyi szolgáltatásokat, a felsőoktatást, a nemzetközi piaci kapcsolatépítö tevékenységet stb. -- és a perifériákra irányitja a hagyományos, kevésbé jövedelmezö termelési ágakat.

A dél-dunántúli gazdaság számára - bár jelenthet rövid távú elönyöket az elmaradott térségek fejlesztésében - ez a megoldás nem lehet stratégiai irányvonal, mert egyértelmúen a régió erősen periférikus vonásokat hordozó szerkezetét konzerválná. A DélDunántúl csak gazdasági autonómiájának erősítésével lesz képes szerkezetének modernizálására, a foglalkoztatottak számának emelésére, jövedelmi kondícióinak javitására.

$\mathrm{Az}$ innovációs potenciál - statisztikai adatokkal már ma is értékelhetö - elemeit vizsgálva, a kirajzolódó kedvezőtlen helyzetkép miatt, megállapíthatjuk, hogy a régió fejlesztési stratégiájában a termék- és technológiai fejlesztés valamennyi tényezöjének és az ezek közötti kapcsolatok kialakitásában érvényesíteni kell a fejlett piacgazdaságok tapasztalatait. Meg kell fogalmazni a $\mathrm{K}+\mathrm{F}$, a technológiai transzferrendszerek fejlesztésének lehetöségeit, javaslatokat kell tenni a magyar technológiapolitika regionális támogatási rendszerének kidolgozására és körül kell határolni a belsô regionális ösztönzések formáit.

\section{A régió gyenge és erös elemei, lehetőségek és veszélyek}

A Dél-Dunántúl gazdasági szerkezetének és társadalmi-településhálózati állapotának az európai és a magyar társadalmi-gazdasági térhez viszonyitott pozicióit elemezve nagy vonalakban - az alábbi következtetéseket vonhatjuk le:

A Dél-Dunántúl gyenge elemei:

- Szélsöséges településszerkezet, az elmaradott települések magas aránya, funkcióhiányos kisvároshálózat,

- Közlekedési peremhelyzet, 
- Leértékelödött természeti eröforrások,

- Kedvezötlen korösszetétel,

- Fejletlen telekommunikáció,

- Korszerütlen iparszerkezet, az exportképes termékek alacsony aránya, kedvezötlen exportszerkezet, a vezetỏ ágazatok versenyképtelensége,

- A belső gazdasági kohézió teljes hiánya,

- Lassú privatizáció, a külföldi tőke csekély érdeklődése, a külföldi vegyes vállalatok alacsony aránya,

- Fejletlen üzleti, pénzügyi szolgáltatások, gyenge $\mathrm{K}+\mathrm{F}$ tevékenység.

A régió erös elemei:

- Geoökonómiai helyzet,

- Viszonylag fejlett, multifunkcionális régióközpont,

- Természeti, gazdasági és etnikai sokszínúség,

- A tercier szektor viszonylag jelentős súlya,

- Az átlagosnál képzettebb munkaerő,

- Kedvező mezőgazdasági adottságok, a minőségi élelmiszeripar fejlesztésének alapjai,

- A piaci intézményrendszer csíráinak megléte, a humán infrastruktúra vertikális rendszerének körvonalai (felsőoktatás-szakoktatás-képzés-átképzés),

- Intézményesült nemzetközi kapcsolatok; interregionális együttmüködések,

- Koordinációs készség a térségfejlesztésben, a partnerségre törekvés igénye.

A fejlesztés lehetöségei:

- A régióban megtalálható - még ha ezek különbözö fejlettségủek is - minden olyan intézmény, amely az új fejlődési pályára lépésben ösztönző szerepet játszhat. E szervezetek - kölcsönös elönyökön és összehangolt fejlesztési stratégián nyugvó - együttmüködése a régió fejlesztésének szervezéséhez fontos erőforrásként veendő számításba;

- A Nemzeti Területfejlesztési Koncepció irányelvei és az új területfejlesztési törvényjavaslat kulcsszerepet szán a decentralizációnak, ennek szellemében - remélhetöleg - átalakul a területfejlesztés finanszírozási rendszere, $\mathrm{s}$ a dél-dunántúli régió és a megyék a beavatkozást igénylö térségekben élő népesség arányában ,alanyi jogon” az elmúlt négy esztendőhöz képest jelentősen nagyobb területfejlesztési támogatásban részesülnek;

- A fejlesztési stratégia szellemében a Dél-Dunántúlon számtalan részprogram és projekt készült, több megyeszékhely fejlesztési koncepciójában fogalmazódott meg a régió gazdasági kohéziója erősítésének az igénye, kirajzolódik az egyưttmüködési készség, ami stratégiai elemmé a megfelelö intézmények létrehozásával alakitható;

- A régió felsöoktatási intézményei, ezek társulásai alkalmassá tehetők az innovációs potenciál erösítésére, a kormány $\mathrm{K}+\mathrm{F}$ stratégiảjában szükséges gyökeres változások esetén megindulhat a technológiai transzferhálózatok szervezése, az egyetemi és a termeló szféra kapcsolatai intézményesülhetnek. A multifunkcionális felsőoktatás alkalmas a fejlesztésekhez szükséges kvalifikált szakemberek képzésére és továbbképzésére; 
Faragó László - Horváth Gyula: A Dél-Dunántúl területfejlesztési koncepciójának alapelemei. Tér és Társadalom, 9. 1995. 3-4. 47-77. p

- A horvát stabilizáció és a délszláv rendezés egyrészt az interregionális kapcsolatok fellendüléséhez vezethet, másrészt szerepet juttathat a Dél-Dunántúlnak az újjáépitésben, elsősorban logisztikai feladatok ellátásával, másodsorban termék- és szolgáltatás exporttal.

Az átalakulást veszélyeztetö tényezök:

- A régió gyenge versenyképességủ gazdasági szerkezete tovább erodálódik, a privatizáció lassan halad, a gazdaság jövedelemtermelö képessége csökken, a régió válságjegyei erősödnek;

- Az Országos Közlekedéshálózat-fejlesztési Koncepció változatlan marad, a tervezett föközlekedési útvonalfejlesztések a következő évezred első harmadában valósulnak meg, a régió elérhetőségi viszonyai nem javulnak, az európai munkamegosztásba való bekapcsolódás esélyei nem módosulnak;

- A gyenge gazdasági szerkezet és a rossz elérhetöség következtében a tercier szektor fejlődése megtorpan, a fejlett szolgáltatások nem telepednek meg, a regionális szükségleteket az ország centrumtérségei elégítik ki, fokozódik a régió külső függése. A belső kohézió megszilárdulása nélkül a régió exportja, külgazdaság orientációja nem változik, a hazai piac kiszolgálása nem ösztönzi a technológiai megújulást, innovációs centrumok nem alakulnak ki, a Dél-Dunántúl követö jellegü gazdasági fejlödésre kényszerül;

- A területfejlesztés új szervezeti rendszerének bevezetésével a megyei területfejlesztési tanácsok „,befelé fordulnak”, felerősödik az érdekellentét a megyék között a külső erőforrások megszerzésért, háttérbe szorul a regionális együttmüködés igénye, a formalizált regionális szerkezet hiánya miatt a központi kormányzat újraelosztó tevékenysége felértékelödik. A megyeszékhelyek fejlesztési stratégiájukban nem építenek a déldunántúli városi munkamegosztásra, érdekérvényesíto erejük gyenge marad, az új intézmények lokális szükségletekre szerveződnek, a városok - kellő funkciók hiján nem kapcsolódnak be az európai városok versenyébe;

- A délszláv válság hosszasan elhúzódik, az interregionális kapcsolatok alacsony szinten maradnak a horvát megyékkel, a belső együttmüködés hiányában a régió nem lesz képes aktív külgazdasági politikát folytatni, európai és nemzetközi kapcsolatai esetlegesek maradnak, kompatibilis infrastruktúra és tudatos fejlesztési stratégia hiján lassan kiszorul az Alpok-Adria együttmüködésből.

\section{A Dél-Dunántúl távlati fejlődésének lehetséges forgatókönyvei}

A régió fejlödési pályája alapvetően három feltételrendszer fủggvénye:

a) a régión belüli eröforrások állapota, felhasználhatósága,

b) a nemzeti gazdaság folyamataiba való bekapcsolódás,

c) a határon túlnyúló, a nemzetközi gazdasághoz való kapcsolódás lehetőségei és formái. 
Ehelyütt csupán a nemzeti tér gazdasági folyamatainak lehetséges hatásait vizsgáljuk. Ezek befolyása elsőrendủ fontosságú, lévén a régió belső kohéziója csekély, az erősen kapcsolódik a (térfolyamatok formálásában döntő szerepú) budapesti gazdasághoz, és az országos szabályozások által megszabott gazdasági mozgásteret a helyi (regionális) szabályozások csak kevéssé képesek módosítani.

Azzal a leegyszerüsítéssel élünk, hogy a jövö forgatókönyveiben a Dél-Dunántúl a magyar gazdasági tér egységeként szerepel, nem vehetőek figyelembe a régión beluili nagy területi különbségek.

A forgatókönyvek összeállításánál a következő elemekból építkeztünk: a gazdasági növekedés, a gazdasági szerkezet átalakulása, a népesség, az infrastrukturális fejlödés, a nemzetközi integrációs kapcsolatok, a környezetvédelem szempontjai. Az elemek rendszerelemzéséböl vonható le következtetés a társadalmi egyenlőtlenségi következményekre, a területi egyenlőtlenségekre és a forgatókönyvben célszerúen alkalmazható területfejlesztési politikára.

A regionális fejlödés elemeinek (egy ,reálisan optimista” társadalmi-gazdasági szcenárión belül maradó) változataiból három forgatókönyv állítható össze, amelyek alapvetöen a területi egyenlőtlenségek szerint különböznek egymástól. A három forgatókönyv: polarizált, közepesen koncentrált és dekoncentrált regionális fejlödés. Rövid jellemzésük a következö:

\section{A) Polarizált forgatókönyv}

- A gazdaság stagnálása - akár belső zavarok, akár az európai recesszió következtében - elhúzódik, a növekedés szelektíven csak az évszázad végén indul;

- Az ipar szerkezeti átalakulása során csak néhány, jelentős külföldi tőkebevonásra képes vállalatcsoport (nem teljes iparágak) indul dinamikus növekedésnek. A tudásigényes iparágak nemzetközi versenyképessége gyenge marad. A mezőgazdaság zavarai az új üzemi viszonyok lassú kialakulása és a keleti piacok elvesztése miatt elhúzódnak, a falusi lakosság széles köre élelmiszerból önellátásra törekszik. A tercier szektorban a felső szintủ termelési szolgáltatások Budapest központúsága megmarad;

- Megújul a vándorlás, az egész országból a budapesti agglomerációba, illetve Nyugat-Magyarország irányába is megkezdódik;

- Az infrastruktủra-fejlesztés - a tőkehiány miatt - követő jellegü marad. Jelentősen fejlődik a telekommunikáció, az út-, vasútfejlesztés a jelenlegi fóvonalak modernizációját (pl. a megkezdett autópálya-építkezések befejezését) jelenti, míg az ország kommunikációs szerkezete nem változik;

- A nemzetközi integrációs kapcsolatok egyoldalúan az EU felé irányulnak anélkül, hogy Magyarország teljes jogú taggá válna. Kelet- és Közép-Európával a gazdasági szálak gyengék és esetlegesek maradnak; 
Faragó László - Horváth Gyula: A Dél-Dunántúl területfejlesztési koncepciójának alapelemei. Tér és Társadalom, 9. 1995. 3-4. 47-77. p

- Az elhúzódó gazdasági pangás nem teszi lehetővé a kárositott környezet helyreállitását. A környezet-terhelés csökken a leépülő́ nehézipari körzetekben, de növekszik az új dinamikus zónákban.

- E forgatókönyv esetén fokozódnak a társadalmi egyenlőtlenségek. A munkanélküliség magas ( $10 \%$ fölötti) szinten marad, $s$ növekszik a munkaerőpiacról végleg kiszorulók száma. A szegénység, a marginalizálódás egyes kistérségekben általános jelenséggé válik.

\section{B) Közepesen koncentrált forgatókönyv}

- A gazdasági növekedés a közeli esztendőkben megindul és az ezredfordulótól már évi $5 \%$ feletti ütemet ér el. A növekedés - különbözö ütemben - az ország valamennyi részén megkezdődik;

- A gazdaság szerkezeti átalakulását technológiai megújulás kíséri. Az új gazdasági szerkezetet nemcsak az elavult ágazatok (termékek) leépülése, hanem néhány új ágazat jelentős elöretörése is jellemzi. Megerösödnek a tudásigényes ágazatok, $s$ az autógyártáshoz hasonlóan új, multiplikátor hatású szakmakultúrák honosodnak meg.

- A mezögazdaságban szerény mennyiségü, de értékes termékszerkezetủ, gazdaságilag jelentős export marad fenn. Kialakul a nagyüzem - családi vállalkozói farm - és a részidős kisgazdaságok hatékony kombinációja.

A tercier szektoron belül a magas szintü szolgáltatások elsösorban Budapesten fejlödnek, de kialakulnak jelentős regionális központok, igy Pécs regionális szerepköre is erösödik. E vidéki nagyvárosok kapu szerepet tölthetnek be saját régiójuk s a szomszédos határmenti régiók között. A vidéki nagyvárosok egyetemi kơzpontjaihoz technológiaiipari parkok, alkalmazott kutatóhelyek csatlakoznak, melyeknek iparvonzó és fejlesztó hatása lesz;

- Az országon belüli vándorlások kis léptéküek, $s$ inkább régión belül maradnak, és ezek erösödő motívuma marad a szakmai mobilitás.

- A hagyományos közlekedési hálózatban megjelennek a régió-közi kapcsolatokat szolgáló vonalak: új hidak, vasúti mellékvonalak felújitása. Javul az ország tranzit képessége, kiépül a belföldi légi forgalom. A vidéki nagyvárosoknak - így Pécsnek is erösödik a szerepe a nemzetközi forgalomban;

- Az ország tagja lehet az EU-nak - más közép-európai országokkal együtt. Emellett újra erösödnének a kelet-európai gazdasági szálak, Magyarország - mint az EU legkeletibb tagja (2005-ig aligha képzelhető el teljes kontinens-méretü gazdasági integráció) Ausztria korábbi kelet-nyugati közvetítő szerepét vehetné át. Ez a Dunántúl további felértékelödését jelenti;

- Növekszik a társadalom környezeti érzékenysége. A környezetvédelmi beruházások új hazai szakma-kultúrák elinditói lehetnek. Az ivóvizellátás és a hulladék-elhelyezés növekvö problémaként jelentkezik. 
- E forgatókönyv esetén is jelentősek a jövedelmi különbségek, $s$ magas marad a munkanélküliség, de a gazdasági élénkülésnek köszönhetően nem kerül sor tömeges elszegényedésre, és jelentösen elörehalad a polgárosodás.

\section{C) Dekoncentrált forgatókönyv}

- Az újrainduló gazdasági növekedés az ezredforduló után, a háború utáni újjáépítési periódushoz hasonlóan felgyorsul, amely Nyugat-Európához való felzárkózást indíthat el. Ehhez különösen kedvezö körülmények szükségesek: megújuló európai konjunktúra, EU-tagság, s ennek következtében jelentős területfejlesztési támogatás, a kelet-ázsiai tökebefektetők megjelenése, számottevő piac-bővülés;

- A gazdasági szerkezetváltás során nem épülnek le teljes iparágak; a technológiai megújulás és az ủj termékek bevezetése lesz a legfontosabb. A tudásigényes és a „zöld" (környezetbarát) iparágak adják a húzóerỏt, de megélénkülnek egyes nehézipari és hagyományos fogyasztási cikkeket gyártó iparágak is.

A mezögazdaság a kettős piac-szervezésnek köszönhetöen jelentősen export-orientált: az EU-n belül magas feldolgozottságú, speciális minóségü termékekkel, Kelet-Európában vetỏmag-, tenyészállat-, know-how exporttal, a termelési rendszerek kiterjesztésével jelentkezik.

A tercier szektorban - a felsỏ szintủ üzleti szolgáltatások mellett - a közszolgáltatások is fejlödnek, sok új munkahelyet teremtve.

- A népességmozgás - a szakmai mobilitáson és az időskorúak vidéki visszaszorulásán kívül - kistérségeken belül marad. A nagyvárosok népessége csökken, agglomerációs gyürüjük kibövül. Az urbanizációs tengelyek összeépülnek, ezek felé népességvándorlás folyik;

- Az infrastruktúra fejlödésében - az elözó forgatókönyvekben is feltételezett általános kommunikációs fejlödésen kívül - két új elem várható. Az egyik az ország Budapest-centrikus közlekedési szerkezetét határozottan módosító régió-közi összeköttetések (mint Déli Autópálya és/vagy hasonló hatású vasútvonal) és az európai nagy kommunikációs rendszerekbe történő beépülés; a másik a lakásépítésnek a városhálózat nagy részében történö jelentős megélénkülése;

- A nemzetközi integrációs fejlödésben a B) forgatókönyvhöz képest is kedvezöbben alakulnak a gazdasági integrációs kapcsolatok Kelet-Európával tehát valódi integrációs szálak alakulhatnak ki Dél-Dunántúl esetében a volt Jugoszlávia utódállamaival;

- Lehetőség nyílik a fenntartható fejlödés elemeinek érvényesítésére, a környezet javuló állapota fontos társadalmi értékké válik. A gyors gazdasági növekedés a környezeti terhelést is erősen növelheti, a környezet-romboló technikai eljárások alkalmazása sem kizárt. 
A forgatókönyveknek az tehát a kiindulópontja, hogy a területi egyenlötlenségek mértéke alapvetően a gazdasági növekedés újraindulási idejétöl és ütemétöl, valamint a kelet-európai gazdasági kapcsolatok újraélénkülésétöl, $s$ ezen belül a határos régiókkal való kapcsolattól függ.

Könnyen elképzelhetỏ egy forgatókönyv-váltás az ezredfordulóig. A közeli jövöre az A) (polarizált) forgatókönyv a valószinủ, ami az ezredfordulón átvált a $B$ ), esetleg a $C$ ) forgatókönyvbe. Az A) forgatókönyv egyes elemei is a B) szerint módosulhatnak.

$\mathrm{Az} A)$ forgatókönyv esetében a Dél-Dunántúl átlagos, illetve periférikus helyzete kevéssé módosul. Ez a forgatókőnyv Budapest újabb erős kiemelkedését idézi (ezúttal nem a politikai-hatalmi, hanem a nemzetközi és az országon belüli pénzügyi-gazdasági funkcióinak kőszönhetően), és jelentös, innovációorientált, fejlett infrastruktúrájú térséggé válhat Nyugat-Magyarország is. A kettészakadó ország fel-felbukkanó viziójának ugyan nincs valós alapja (az ország minden részét számos gazdasági kapcsolat fủzi a budapesti gazdasághoz), de az elmaradott térségek lemaradása fokozódhat.

E polarizált fejlödési forgatókönyvbe „,belefér” mindenekelött Pécs és néhány középváros (megyeszékhely) fejlödése, attól függően, hogy mennyit tesznek eröforrásaik dinamizálásáért. Jelentös fejlödés, regionális szerep azonban nehezen prognosztizálható a régió rossz közlekedési viszonyai miatt, amelyek e forgatókönyv szerint aligha javulnak a közeljövöben. Pécs innovációs központ szerepét is gyengíti $K+F$ szektorának fejletlensége és kedvezötlen szerkezete. A régió nagy belsö és határmenti perifériáin a teljes elnéptelenedés is jelentkezhet. A jelenlegi területfejlesztési politika ugyan prioritást ad a legelmaradottabb településeknek, ám ez legfeljebb az életkörülmények romlását fékezheti, de a fejlödés termelési tényezöi mesterségesen nem teremthetỏek meg.

A B) változat a régiónak a fövárostól való gazdasági fuuggöségét enyhít. Pécsen kivül a középvárosok is jelentösen erösítik pozícióikat, valamennyien részt vehetnek (a maguk kategóriájában) a nemzetkőzi városversenyben $s$ helyi gazdaságuk önállóbbá válhat. Pécs regionális központ szerepköre innovációs központ, pénzügyi központ és ,,déli kapu" funkciókkal bővülhet. A régió kommunikációs kapcsolatai javulnak. A falusi népességváltozásokat egyes speciális agrártermékek ( $\mathrm{pl}$. villányi bor), az idegenforgalom és a városi agglomerációk bövülése fogja befolyásolni; a faluállomány egy részében az elnéptelenedés tovább tart.

$\mathrm{A} C$ ) változat esetén a gazdasági élénkülés még nagyobb területre terjedne ki a régión belül. Ebben az esetben a kommunikációs helyzet javulásával tapasztalható lesz a kedvezö természeti adottságú elhagyott falvak újratelepülése, mivel bekerülhetnek a területileg fellazuló urbanizált zónákba, lakooövezetekbe. Nem valószínü, hogy a régió egészének periférikus helyzete az országon belül megváltozik - a jelenlegi dinamikus régiók elönye (egy bö évtizedre elöre tekintve) tartósnak látszik. A gazdaság és a lakossági életkörülmények szinvonala azonban általában növekszik és a régióban szükülnek a marginális, elszegényedett területek.

Ezek az általános trendek meghatározzák a Dél-Dunántúlnak az országon belüli helyzetét - az ezredfordulóig sem a településhálózat elönytelen vonásain, sem a kommu- 
nikációs kapcsolatok fejletlenségén ugrásszerü, minőségi változás nem várható. A régión belül már nagyobb a mozgási szabadság, elsősorban a jelentősebb városok közül néhány - sikeres tökevonzás és intézményfejlesztés esetén - alaposan kiemelkedhet. A települések fejlödésében kitüntetett szerepe van a helyi gazdasági szereplöknek. A kistérségi fejlesztés is csak ezekhez a dinamikus központokhoz kapcsolódva képzelhető el.

\section{A regionális fejlesztés prioritásai}

A régió fejlesztésének hosszú tóvú stratégiai célja az, hogy a belső eröforrásokra és adottságokra épitve a Dél-Dunántúlon az általános fellendülés feltételei megteremtődjenek, javuljon az életminőség, a térség egy fejlödỏ ország prosperáló régiójává váljon. Ez az általános célkitủzés egyrészt generális politikai irányvonal, másrészt fejlesztési prioritások megfogalmazását teszi szükségessé.

1) A Dél-Dunántúl fejlödését elsősorban saját eröforrásaira alapozva kell megoldani. Nem kis feladat ez egy olyan országban, amelynek nemzetgazdasága sem képes saját tỏkefelhalmozásból fejlödését biztosítani, ezért e követelmény csak megszorításokkal alkalmazható egy átlagos fejlettségü, de az átlagosnál tớkeszegényebb régióban. Ezért e kiinduló elv pontosításokra szorul, amit a központi szerveknél is tudatosítani szükséges:

- A külföldi müködỏ tőke bevonása - megfelelö strukturális és finanszírozási feltételek mellett - a jövöben a jelenleginél fontosabb eszköze legyen a régió fejlödésének. Ezáltal Budapest és a központi régió túlzott koncentrációját is mérsékelni kell. Ebben feladat hárul az állami privatizációban résztvevõ döntéshozókra és a külpolitikára, de a régió önkormányzatainak is eröteljes területi marketing tevékenységet kell folytatniuk.

- A fenti alapelv nem vonatkozik az Európai Unióba való belépés esetén az EU strukturális alapjaiból való részesedés jogosultságára és igényére, aminek intézményi alapjait ugyancsak központi segitséggel kell kialakitani.

- A régió jogosult a területfejlesztés támogatási alapjaiból nyújtott azon forrásokra, amelyek a kedvezményezettség objektív kritériumai alapján megilletik. Amennyiben a régió elmaradott és válságtérségei nem képesek a pályázatok adta lehetöségekkel élni, akkor a KTM-nek sajátos preferenciák kidolgozásával kell biztositania a központi alapok szükségletekkel és a jogosultsággal arányos felhasználását.

2) A források nagyobb arányú helybentartása és hatékonyabb hasznositása azonban még nem elegendö a helyi bázisú fejlödés feltételeinek létrehozásához. A növekedési impulzusok „helybentartásához” ugyanis a reálszférában is szükséges a belsõ integráció növelése, a helyi vagy térségi gazdasági, szállitási, szolgáltatási kapcsolatok intenzitásának növelése:

- Ennek egyik eleme a gazdasági klaszterek kialakulásának támogatása. Különösen a Dél-Dunántúl viszonylag decentralizált, szétszórt gazdaságában nélkủlözhetetlen a fejlödés „,továbbközvetítése” nemcsak kölcsönös beszállitások formájában, hanem kisebbnagyobb vállalkozások megvalósittásánál „konzorciumok” létrehozásával, a közbe- 
szerzésekben a helyi vállalkozások preferálásával, az információk cseréjében. A gazdasági klaszterek kialakításában kiemelkedő jelentősége van a Gazdasági Kamaráknak, valamint a helyi szakmai, vállalkozói, esetleg tanácsadó szervezetek tevékenységének.

- A másik elem az üzleti, információs, kereskedelmi és technikai jellegü szolgáltatások nagyobb mértékü integrálása, ráépitése a szükebb termelö tevékenységre. Ez küłönösen fontos az átalakuló mezögazdasági üzemszervezet és az ehhez még nem alkalmazkodó termelöeszköz ellátási, tanácsadási, értékesítési szervezet összehangolásában, de általában a megsokszorozódó számú vállalkozások és a kereskedelmi, szállitási, üzleti, információs szolgáltatások újonnan felépítendö kapcsolatrendszerében is, beleértve a kutatást, a müszaki fejlesztést, az információ- és az innováció-továbbítást is. Ugyanez a helyzet az oktatás, képzés, átképzés és az üzleti szféra kapcsolatrendszerében.

3) Mivel a Dél-Dunántúl gazdasága - az ország nagy régiói közül - a legkevésbé exportorientált fejlödése - a belföldi felhasználás korlátozottsága miatt - csak az exportra támaszkodhat, az exportorientáció kiépitése tehát létfontosságú.

Az általános exportösztönzés (pl. valutaleértékelés) eszközrendszere nem elegendö, ez csak az élelmiszeripari termékeknél játszhat szerepet. Sajátos eszközökre van szükség, mert egyelöre nincs meg az exportárualapot megtermelő potenciál. Ezt az általános exportösztönzéssel lehet serkenteni. Geopolitikai helyzetéből adódóan a DélDunántúlnak az Alpok-Adria makrorégió gazdasági hálózataihoz célszerủ kapcsolódnia. Az illetékes tárcának, a gazdasági kamaráknak és az újonnan megalakuló Regionális Fejlesztési Tanácsnak elsősorban az exportösztönzésre kell konstrukciókat kidolgoznia és alkalmaznia. Ennek egyik kiegészítỏ eleme, hogy e térség kereskedelmi kirendeltségei egy dél-dunántúli tanácsos tevékenységét közösen finanszírozzák.

4) A Dél-Dunántúlon az infrastruktúra a szük keresztmetszet. Vonatkozik ez elsösorban a közlekedési, hírközlési kapcsolatokra, továbbá a (felsö) oktatásra, kutatásra. Ezek fejlesztésére a kompetens minisztériumoknak dél-dunántúli programot kell kidolgozniuk.

5) A kormányzat a területfejlesztési intézmény-és szervezetépitést is a válságtérségekre koncentrálta. Ám nem ott kell elsősorban regionális fejlesztési intézményrendszer, ahol központi pénzekböl központi programokat hajtanak végre, hanem ott, ahol a regionális döntéseknek és eszközöknek komoly szerepet szánnak. A Dél-Dunántúl esetében a kistérségi és megyeközi szervezödések kompetenciájának, hatáskörének, müködésének, jogi-intézményi feltételeinek kialakitása igényel központi támogatást. 


\section{Térségi és ágazati programok}

\section{1. program: A falusias térségek üjjászervezése, vidékfejlesztés}

A térség sajátos problémája az aprófalvas szerkezet. Az ország 500 főnél kisebb települései lakosságának 46\%-a, az 500-1000 lakosú településeken élőknek 30\%-a a Dél-Dunántúlon lakik. Ráadásul - miközben e településekben nagy a természetes fogyás és elvándorlás - az e telepủléskategóriákban élö régióbeli lakosság száma fokozatosan nỏ, mert egyre több, korábban nagyobb népességú település ,csúszik le” ebbe a kategóriába. Az aprófalu-probléma tehát - eltérően a tanyakérdéstöl - nem csökkenő, hanem növekvő gond.

Az elmúlt években sok új tanterem épült, illetve újjáépült, javult az aprófalvak vízellátása és úthálózata. A nagy termelőszövetkezetek átalakulása számos kis falunak visszaadta a gazdasági szervezőközpontot, az új önkormányzati rendszer pedig a saját helyi kormányzatot. Mindezek a változások nem hatottak a jövedelemhiányra, az elvándorlásra, az elöregedésre, a közlekedési feltételek és ezáltal az ingázási feltételek módosulására és általában a szociális viszonyok javulására. Az aprófalvak fó gondja ma már nem az iskolák hiánya, hanem az általános elmaradottság, az idős népesség, a szociális segélyre rászoruló munkanélküliek problémája. A céltámogatási rendszer preferenciáival szükségszerüen torzította a helyi valós prioritásokat. Ugyanakkor ezek a fejlesztések ma olyan elkötelezettségekkel terhelték meg az aprófalvak költségvetését, melyek korlátozzák az aprófalvak problémáinak megoldását.

A kistérségi együttmüködés alapvetó feladat. A megyei preferenciákon kívül a központi alapok szabályozásába is be kell építeni a térségi együttműködés priorizálását.

2. program: Balaton-problematika: a környezetvédelem, a gazdaság és idegenforgalom integrációja

A program elsödlegesen gazdasági orientációjú, így elsősorban ebböl a szempontból kell kezelnie e kérdést. Korábban a balatoni idegenforgalom csak a déli parton állandó jelleggel 30-40 ezer, idényben több mint 100 ezer embernek biztosított megélhetést, munkahelyet. A dekonjunktúra következtében harmaduk-(felük) jövedelemforrását, munkahelyét veszitette el. Ehhez járul a befektetési veszteség, a megtérülés elmaradása, a nemzeti vagyon elértéktelenedése (az elértéktelenedésből való veszteség csak a déli parton kb. 20 milliárdot tesz ki). A szigorú környezetvédelmi szempontokat figyelembe véve diverzifikálni kell a térség gazdaságát. E programban a „leszivott” háttér települések, körzetek jelentös szerepet kaphatnak. E preferenciákat be kell építeni a készülö balatoni koncepciókba, tervekbe. 
Faragó László - Horváth Gyula: A Dél-Dunántúl területfejlesztési koncepciójának alapelemei. Tér és Társadalom, 9. 1995. 3-4. 47-77. $p$

\section{3. program: A Dráva-Duna Nemzeti Park létrehozása}

A Duna Sió torkolat alatti szakaszán és a Dráva mentén kialakitandó nemzeti park területe 50000 ha. A park célja e folyók, mellékágrendszerük, valamint az érintett területek természeti értékeinek, a felszíni és a felszín alatti vízkészleteknek, az érintett területek erdeinek, termőtalajának és más megújuló erőforrásainak védelme. A terület természeti oltalma, a parkhoz kapcsolódó gazdasági tevékenységek hozzájárulhatnak a térség fejlödéséhez.

A nemzeti park létesitésének koncepciója elkészült, mihamarabb kormányzati döntés szükséges ahhoz, hogy a régió elsö kiemelt természetvédelmi körzete megkezdhesse müködését.

4. program: Pécs-Komló térségének urán-és szénbányászata: a termelés fokozatos megszüntetése, az eröforrások újrahasznositása, tájrehabilitáció

Bár a bányászat ebben a térségben már csak hétezer föt foglalkoztat, a kérdés gazdasági és társadalmi súlya igényli a kormányzati szintü közremüködést. A feladat több tárca összefogását igényli az 1994-ben elfogadott kormányhatározat alapján.

\section{5. program: A gazdasági klaszterek fejlesztési programja}

A gazdaságfejlesztés bázisa a versenyképes ipari termelés és a hozzá kapcsolódó termelö szolgáltatások megerösödése lehet. A dél-dunántúli régió mai gazdasági szerkezetében túlnyomóan hagyományos ágazatok dominálnak, amelyek exportképessége csekély, emiatt a régió külgazdasági orientációja folyamatosan gyenge eredményeket produkál. A piacgazdaság kiépülésének elsö jeleként megindult reindusztrializálódást (az ipar szerkezeti átalakulását) a nemzetközi versenyképesség erösítésével, az exportértékesítés arányának növelésével kell összekapcsolni. Ezért olyan ipari fejlesztési stratégiát célszerü kidolgozni, amely számba veszi az ipari versenyképesség valamennyi elemét (az innovációs láncot) és kiválasztja a külpiacokon exportképes, fejlesztendö ágazatokat. Az ipari exportkapacitások fejlesztését azért tekintjük prioritásnak, mert egyrészt a DélDunántúl exportjában kétharmados arányt jelentenek, másrészt az innovációs színvonal emelésére, a technológiai megújulásra ebben a gazdasági ágban van a legnagyobb szükség, harmadrészt a régió geoökonómiai pozíciója és komparativ előnyei az iparfejlesztés számára kedvezöek. A nemzetközi hálózatokhoz való kapcsolódás feltételei is ebben az ágazatban alakithatók ki viszonylag leggyorsabban.

A magyar gazdaság közös piaci exportjának - és felméréseink szerint a Dél-Dunántúl kivitelének is - nagy részét élelmiszeripari, könnyüipari termékek, gépek, berendezések adják. Ezek lényegében olyan alaptermékek, amelyek kereslete az EU országokban lassan emelkedik, s értékesítésükben éles verseny tapasztalható. $E$ magyar termékek 
exportja a nyugat-európai importkorlátozások fokozatos mérséklésétöl függ, valamint a hagyományos EU szállítókkal közel azonos versenyképesség elérése esetén bövülhet. A társulási szerzödés ratifikálása az elsỏ feltétel teljesülése szempontjából kedvezönek minősíthetö, a második követelmény azonban a dél-dunántúli termékek számára mielöbb elérendö célkitüzés.

A dél-dunántúli ipar szinte valamennyi ágában 1997-ig lassú növekedés prognosztizálható. A régió termelỏi e szektorokban tehát rendkívül nehezen juthatnak új pozíciókhoz a közeljövőben.

A magas arányt mutató ágazatokban a versenyképesség megteremtésének a munkatermelékenység (a technológiai megújulás) emelése az előfeltétele; a Dél-Dunántúl meghatározó ágazatainak nagy része ebbe a kategóriába tartozik.

A régió iparfejlesztési stratégiájának kidolgozása során a tervezók nem lesznek könnyủ helyzetben. Az elektronika, a mủanyag- és a faipar kivételével valamennyi más ágazatban az exportkapacitások bővítése jelentős beruházásokat igényel. $\mathrm{E}$ befektetések - a bútoriparban és az élelmiszer-feldolgozás egyes területein -, valamint új, versenyképes ágazatok meghonosítása elengedhetetlen előfeltétele annak, hogy a régióban versenyképes, exportorientált iparszerkezet alakuljon ki.

A gazdaságfejlesztés követendö alapelvei, valamint az exportképesség fejlesztése abban az esetben érvényesíthetök, ha a privatizáció újabb szakaszában, illetve a külfờldi töke orientálásában a kormány - iparfejlesztési koncepciójának keretei között - a DélDunántúlon néhány multinacionális nagyvállalat letelepedését szorgalmazza. E nélkül a régió nem képes arra, hogy ipari értékesitésében megközelítse a 25\%-os országos exportráta átlagot és exportját kb. 15-18 milliárd Ft-tal növelje.

E program dőntơ eleme, hogy a gazdaságot nem csak ágazati vagy profitorientált megközelítésben vizsgálja, hanem vertikálisan és horizontálisan integrált, a régióban gyökerezỏ klaszterekben. E megközelítés segíthet abban, hogy a régió döntéshozói - a közösségi és magánszektorban egyaránt - olyan újszerủ stratégiai és taktikai döntéseket hozzanak, amelyek új pályára terelhetik a regionális gazdaság fejlődését.

A programalkotás nehézségei:

- A régióban termelt áruk piaca csak lassan nó;

- A verseny a világpiaci és EU-hoz való integrálódásunkkal erősödik;

- A régió hagyományos komparatív elónyei gyengülnek;

- A korábban legnagyobb jövedelemtermeló bányászati klaszter hanyatlik és magával rántja a körzet gazdaságát is;

- A gazdasági szolgáltatások fejletlenek és maguk is támogatásra szorulnak.

Ezért a gyengülỏ komparativ előnyöket új versenyképes elemekkel kell kiegésziteni:

- Új versenyképes gazdasági klasztereket kell kialakítani vagy reorganizálni;

- Fejleszteni kell a helyi igényeket kiszolgáló gazdasági infrastruktúrát;

- Az EU piacára kell koncentrálni (ami ott versenyképes, az bárhol eladható a világon);

- Erösíteni kell a közösségi és a magánszfẻra együttmüködését. 
Faragó László - Horváth Gyula: A Dél-Dunántúl területfejlesztési koncepciójának alapelemei. Tér és Társadalom, 9. 1995. 3-4. 47-77. p

6. program: A mezögazdaság fejlesztése: differenciált támogatások

A dél-dunántúli régió volt a szarvasmarhatartás, a marhahús- és tejtermelés szempontjából az ország legintenzívebb területe. Ez az ágazat az elmúlt öt évben mély válságba került. Belső és külső piacainak jelentős részét elveszítette, hazai takarmánybázisa nem volt elég korszerü, az import pedig rendkívüli mértékben megdrágult. A mezögazdaság tökevesztése és az átalakulás zavarai ezt a tőkeigényes és hosszú távra fejleszthetỏ ágazatot sújtotta legjobban. Végül, de nem utolsósorban a piacok nyitása egyre nyilvánvalóbbá tette, hogy Nyugat-Európa éghajlati, földrajzi adottságai ezen ágazat tekintetében jobbak, ráadásul a jobb adottságok mellett épp ezen ágazat kapja a legnagyobb mértékü támogatásokat. Az ágazat nemzetközi, különösen európai versenyképességének romlása tehát tartós folyamat, de a jelenlegi visszaesés mértéke meghaladja a gazdaságos export és a hazai piac valós, hosszú távú felvevőképessége által meghatározott mértéket is. Egy ésszerú agrárpolitika a hanyatlást megállíthatja - és meg is kell állitania -, de az eredeti arány és színvonal valószinüleg nem fog visszatérni. A régió fö állattenyésztő körzeteiben ezért struktưraváltásra van szükség.

A strukturális átalakulás fö irányai a növénytermelés kisebb piaci rései, a lucerna, a takarmányborsó, a repce, a szója, esetleg (az iparágakat meghatározó külföldi befektetök stratégiájának függvényében) a dohány és a sörárpa termesztésének minöségi fejlesztése. Az ún. ,apró cikkeknek" (méz, nyúl, vad, béka stb.) tovảbbra is kedvezőbb piaci kilátásai vannak, mint a nagy volumenü alaptermékeknek.

A feldolgozásban valószínüleg még élesebben fog elválni az EU normáit teljesíteni képes szektor, amely beszállítóit keményen szelektálja és szigorú követelményeknek veti alá és az e feltételeket nem teljesítő, hazai ellátásra berendezkedő szektor, amely kategóriában a jövőben is számos (mind kis- és közepes, mind nagy-) üzem felszámolásával és bezárásával számolni kell.

Segiteni kell a piacorientált középgazdasági típus kialakulását. A kisgazdálkodók támogatása csak integrált és specializált termelés esetén indokolható. Azokban a falusias térségekben, ahol a piacképes termelés nem bövíthető, alternatív tevékenységeket kell támogatni, elsősorban foglalkoztatási, méltányossági szempontokból.

\section{7. program: Az erdöterületek védelme: központi újraszabályozás}

A dél-dunántúli régióban található az ország erdőterületének $28 \%$-a, 479 ezer hektár erdö, favagyonának $35 \%$-a. Zala megyében van az ország legnagyobb kiterjedésủ erdöterülete. A ma végbemenö üzemszervezet átalakulás, kárpótlás talán a legnagyobb mértékben az erdőterületeknél váltott ki súlyos helyzetet. Ez a Dél-Dunántúlt, mint az ország legerdősültebb térségét különösen fenyegeti.

Az új tulajdonosok közül számosan - és a jelenlegi helyzetben némileg érthetỏen rövid távú haszonra törekszenek az erdök kivágásával. Az eddigi szabályozás ennek 
részben gátat tudott szabni, de csak a tulajdonosi jogok korlátozásával. A jelenlegi jogi és használati helyzet ellentmondásai nem sokáig tarthatóak, szükséges a kérdés átfogó törvényes szabályozása.

Emellett indokolt az ủj erdőtelepítések számára továbbra is preferenciát nyújtani, különös tekintettel az új tulajdonosokra.

\section{8. program: A turizmus fejlesztése}

A turizmus fejlesztésében fel kell számolni a Balaton-nimbuszt és az adottságokat szélesebb merítésböl hatékonyabban kell hasznosítani. A turisztikai termékeket térségi alapon vagy komplex programokra felfüzve kell piacositani. Bövítendỏ a már meglévő kapacitásokat is jobban hasznosító tudományos-üzleti-hivatásturizmus. A kiváló minöségủ gyógyvizekre alapozva továbbfejleszthető a gyógyturizmus. A régió különlegessége lehetne az eltérö karakterü borvidékekre épülö borturizmus. A Balaton esetében nyáron a családi üdülés, mig szezonon kivuül a harmadik korosztály vonzása növelheti a féröhelyek kihasználását. A turizmus fejlesztését össze kell kapcsolni a kulturális és a médiaipar megerösítésével, illetve a szakoktatás reformjával.

\section{9. program: Közútfejlesztés}

A Dél-Dunántúl viszonylag hátrányos helyzetének egyik meghatározó eleme a közlekedés helyzete és állapota. Autoút egy szakaszon a régió peremén van csak, a megyeszékhelyek egymással való összeköttetése is kívánnivalókat hagy maga után. A terület egy jelentös részén hiányzik a közvetlen összeköttetés a megyeszékhelyekkel, továbbra sincsenek komoly és belátható időn belül megvalósuló tervek a Budapestet elkerülö kelet-nyugati összeköttetés déli nyomvonalára. Makrogazdasági célokat - az ország nagy tájainak kohézióját - szolgálná Szekszárd és Mohács térségében közforgalmú Duna-híd építése.

A déli transzverzális közúti vonal megépítése - Nagykanizsa-Kaposvár-DombóvárSzekszárd útvonalon - a régiónak is megteremtené az ország más részei, valamint Szerbia, Románia, Ukrajna és Szlovénia, Horvátország, Ausztria felé a kedvezöbb közúti kapcsolatot. Az M7-es autópálya meghosszabbitása Nagykanizsa irányában nemzetközileg ugyanezt az irányt szolgálná, de a régiónak csak kisebb részét tárná fel.

A másik feladat a régió nagyvárosai közötti gyorsabb és biztonságosabb közlekedési lehetöség megteremtése. 14 városban van szükség a település központját megkerülö útvonalakra.

Sürgetö feladat a Dél-Dunántúl közúthálózat-fejlesztési programjának felülvizsgálata. 
Faragó László - Horváth Gyula: A Dél-Dunántúl területfejlesztési koncepciójának alapelemei. Tér és Társadalom, 9. 1995. 3-4. 47-77. p

TÉT 1995 • 3-4 A Dél-Dunántili területfejlesztési koncepciójának alapelemei

69

10. program: Regionális repülötér-fejlesztés

A régiónak nincs közforgalmú repülötere. A fejlesztéshez központi segítséget és nemzetközi tökét is igénybe kell venni. A meglévö adottságok, illetve a prognosztizálható kereslet és a gazdaságfejlesztési irányok alapján eltérö funkciójú, hasznositású és méretü repülöterek összehangolt fejlesztési programjának kidolgozására van szükség (Pécs: közforgalmú személy és teher, Taszár: teherforgalmi, Sármellék: időszakos idegenforgalmi hasznositás).

\section{1. program: Az innovációs lánc alapelemeinek megteremtése: $a K+F$ szektor és a technológiai transzfer fejlesztése}

Mivel a régió innovációs potenciálja hagyományosan gyenge, a tudásigényes ipar és a nemzetközi piacokon versenyképes szolgáltatások fejlọdése annak lényeges megerōsítése nélkủl elképzelhetetlen. A fejlesztések bázisai a régió erős kutatási kapacitással rendelkező felsőoktatási intézményei lehetnek, a felsőoktatás fejlesztésében a régió stratégiai szükségleteit (technológiai váltás, versenyképes termékszerkezet, külgazdasági orientáció) érvényesíteni kell. A termelés és a kutatás kapcsolatait tudományos-technológiai transzferközpontokkal kell intézményesíteni a potenciális kutatási bázisokra (Pécs, Kaposvár, Keszthely) telepítve.

A minöségi termeléshez szủkséges szaktudás és kreativitás a jelenlegi képzési és továbbképzési hálózatok átalakitását igényli. A post-secondary képzést e céloknak kell alárendelni.

A technológiai váltás és a müszaki innováció a kis- és középvállalati szféra fejlödésének is alapvető feltétele.

\section{2. program: A nemzetközi együttmüködések fejlesztése}

A régió fejlödése szempontjából nagy jelentősége van a régió területi egységei, önkormányzatai, gazdasági kamarái, vállalkozásai nemzetközi kapcsolatrendszerének.

Ennek egyik kerete az Alpok-Adria Munkaközösség, a másik a Duna menti Régiók Szövetsége. A Dráva mente, annak természetvédelmi szempontból értékes övezetei, a folyó komplex hasznositása kínálja magát a regionális (kistérségi) együttmüködésre.

A geoökonómiai adottságok kihasználhatósága érdekében decentralizálni kell a nemzetközi gazdasági és társadalmi kapcsolatok egy részét. Ez összhangban van az EU csatlakozásra való felkészüléssel, illetve az Európa Tanács ajánlásaival. A területi szint megerösítése, „külpolitikai” jogosítványokkal való felruházása segíthet a már müködő regionális integrációk intenzifikálásában. A regionális külkapcsolatok közé sorolható a gazdasági információcsere és együttmüködés, kooperáció a $\mathrm{K}+\mathrm{F}$ területén, együtt- 
müködés a szakképzésben és a felsőfokú oktatásban, infrastrukturális fejlesztések egyeztetésében, a környezetvédelem területén stb.

A kétoldalú vegyes bizottságokban biztosítani kell a régió képviseletét. Az interregionális kapcsolatok fejlesztéséhez elengedhetetlen a közúti határátkelöhelyek számának gyarapitása.

\section{3. program: Befektetési társaság, fejlesztési intézet létrehozása, a meglevö intézmények támogatása}

Valamennyi nagyrégió közül a Dél-Dunántúl rendelkezik a legdiszperzebb, legelaprózottabb megtakaritásokkal, pénzügyi eröforrásokkal, önkormányzatai a legkisebbek, legnagyobb számúak, amelyeknek betétei egyenként kicsik, de összességében nagy forrást jelentenek. Üzemeinek mérete viszonylag kisebb, gazdasága kevésbé koncentrálódik egy szükebb körzetre, egy-két nagyvárosra, mint különösen az alföldi és északi régiók esetében. Következésképpen a Dél-Dunántúlon szükséges leginkább befektetési társaságok, a forrásokat összegyüjtő és helyileg hasznosító társulások létrehozása. Ezek létrejöhetnek a lakossági, az önkormányzati és a vállalkozási szférában külön-külön, de még ésszerübb lenne azok kombinációja. Ezen intézmények (befektetési társaságok, önkormányzati vagy regionális bankok, önkormányzati fejlesztési társulások, a takarékszövetkezetek helyett vagy mellett valódi hitelszövetkezetek) alapítása ugyancsak a saját forrásokon alapuló fejlesztés elöfeltétele.

\section{Beavatkozási területek a Dél-Dunántúlon}

A fejlesztési programok egy része kistérségekre, más részük településekre lokalizálható, a vonalas infrastrukturális fejlesztések pedig a régió több mikrokörzetét füzik fel. A Nemzeti Területfejlesztési Irányelvek ajánlásait követve a Dél-Dunántúlon öt beavatkozási tértípus határolható le, az egyes tevékenységek hatékony megszervezésének gazdasági és piaci követelményeit mérlegelve a telepitésre alkalmas települések, elsősorban városok is meghatározhatók.

A sajátos strukturális, fejlödési gondokkal küzdỏ térségek a felvetődö problémák és az alkalmazandó stratégia típusai szerint osztályozhatók. Indokolt, hogy e vonatkozásban az Európai Unióban alkalmazott - támogatást vagy sajátos kezelést igénylö - térségtípusokat vegyük alapul és ezeket adaptáljuk a régióra. (Annál is inkább, mert a strukturális alapok jelentős részének elosztása az EU-ban e térségtípusok szerint történik.) A meghatározott problématipusokhoz kapcsolódó lehatárolásból következik, hogy a térségek nem fedik le a régió egész területét, illetve ugyanaz a térség többféle problématípusba is beletartozhat. E térségtípusok a Dél-Dunántúlon az alábbiak (2. ábra):

- Gazdasági és társadalmi szempontból elmaradott régiók, 
- Ipari hanyatlás által sújtott térségek,

- Rurális (mezőgazdasági) területek,

- Környezeti szempontból kiemelten kezelendỏ térségek,

- Határmenti térségek.

A Dél-Dunántúlon nyolc kistérség (a KSH kistérségi lehatárolását figyelembe véve), a letenyei, a zalaszentgróti, a csurgói, a barcsi, a tabi, a sellyei, a siklósi és a tamási tartozik az elmaradott térségi kategóriába.

A depressziós térségi kritériumoknak a Dél-Dunántúlon csak két kistérség, a komlói és részben a bonyhádi tesz eleget. $E$ térségekben a támogatási célok lényegében azonosak az elmaradott területekkel. A feltételek és módszerek azonban mások. A korábban kialakult nehézipari bázis inkább hátrány, mint elöny a szerkezeti átalakulásban, mert sokkal több determináló adottsággal, konzerváló érdekkel és politikai érdekérvényesitéssel kell számolni. A környezeti problémák is súlyosabbak, mint más területeken.

A feladat nagyságrendje és a helyi érdekrendszer bonyolult volta miatt elkerülhetetlen az állam közvetlen részvétele a szerkezetváltásban, azaz - nemzetközi forrásokból támogatott - átfogó szerkezetátalakítási programozás megvalósítása, amelyhez itt elsősorban szakmai befektetökre van szükség, ezektöl korszerüsités, piac- és munkahelyteremtés remélhetö.

A kritériumok helyi feltételeknek megfelelö rugalmasabb alkalmazásával 13 kistérség minösithetö jelentôs arányban rurális jellegünek. Ezek az alábbiak: a lenti, a letenyei, a zalaszentgróti, a csurgói, a marcali, a nagyatádi, a barcsi, a tabi, a szigetvári, a sásdi, a mohácsi, a dombóvári és a paks-dunaföldvári kistérség.

A környezeti szempontból kiemelten kezelendö térségek a környezetgazdálkodás érdekében egységes rendezést igénylö területek a kiemelkedő jelentöségü természeti értékek védelme érdekében vagy sokféle, eltérö környezet- és területhasználati érdek egyidejü összehangolása miatt beavatkozásra szoruló térségek. Ezek a térségek a DélDunántúlon:

- a kiemelt üdülökörzetek (a Balaton környéke),

- a leendö nemzeti park (a Dráva-Duna Nemzeti Park),

- a bányarehabilitáció térségei (Pécs, Komló és a bonyhádi kistérség).

A kormányzat a hozzájárulás elvén támogatja e térségekben a környezet és a természet állapotának megóvását (vagy javítását, helyreállitását) szolgáló célkitüzéseket. Koordinációs szerepében előmozdítja a területhasználat megváltozásával járó fejlesztések összehangolását.

A határmenti térségek három típusa különböztethetö meg.

Az első a nyugati határmenti megye (Zala), amelyre kiterjed a PHARE-INTERREG II. program. E térség már létezö, nemzetközi megállapodások alapjản a nyugat-magyarországi megyékkel közösen végrehajtott fejlesztési programok akcióterülete. A fejlesztés tartalmát nemzetközi megállapodások határozzák meg, a finanszírozás is részben nemzetközi forrásokból történik. A fejlesztés végrehajtásában a központi és térségi szervezetek a partnerség alapján vesznek részt. 
Faragó László - Horváth Gyula: A Dél-Dunántúl területfejlesztési koncepciójának alapelemei.

Tér és Társadalom, 9. 1995. 3-4. 47-77. p

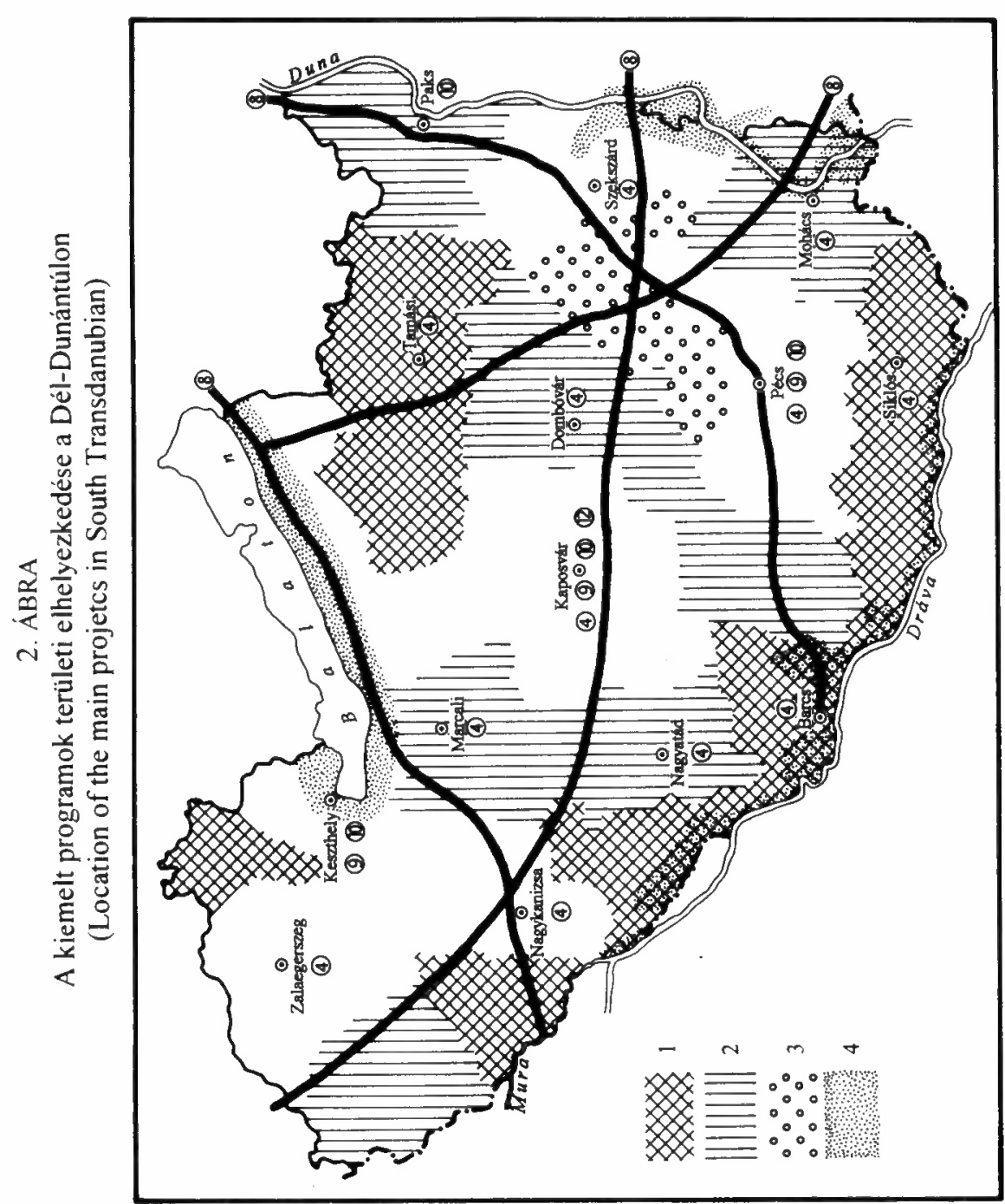


Faragó László - Horváth Gyula: A Dél-Dunántúl területfejlesztési koncepciójának alapelemei. Tér és Társadalom, 9. 1995. 3-4. 47-77. $p$

A régió többi határmenti térségében jelenleg ilyen program nem létezik, és megszervezódésük esetén a külsỏ finanszírozásra kisebb az esély. Jellegük szerint e térségeket indokolt két csoportba osztani.

Az egyik csoportot a nemzetközi forgalmú határátkelöhelyek hatásterületei alkotják, amelyek alanyai a nemzetközi forgalom pozitív és negatív következményeinek (letenyei, barcsi, siklósi és mohácsi kistérségek). E térségekben elsősorban a határátkelés civilizált és gyors lebonyolításának feltételeit kell megteremteni, minél kisebbre csökkentve az ezzel járó környezeti és kriminális hatásokat, támogatva a gazdasági és más együttmúködésre irányuló kezdeményezéseket, közös termelési és fejlesztési javaslatokat.

A másik csoport a nemzetközi határátkelöhellyel nem rendelkező és ennek következtében elszigetelödött, periférikus helyzetủ térségek csoportja. Amellett, hogy az átjárhatóság (kishatár-átlépés) feltételeinek megteremtésére itt is törekedni kell, egyúttal meg kell akadályozni e térségek elnéptelenedését, részben a megközelithetőség javításával, részben az elmaradott térségek támogatásával azonos értékủ eszközökkel (lenti, csurgói, sellyei kistérség).

A határmenti térségek fejlesztését - ott, ahol megfelelö szervezỏ centrumtelepülés található nemzetközileg frekventált közlekedési erőtérben - jól szolgálhatják a vállalkozási övezetek. A Dél-Dunántúlon Letenye, Barcs és Mohács lehet alkalmas e funkció ellátására.

Összegezve a dél-dunántúli beavatkozási területek besorolásának tapasztalatait, azt látjuk (3. táblázat), hogy a régió szinte minden kistérsége (kivéve a megyei jogú városok körzeteit) besorolható valamilyen támogatási típusba. A területfejlesztésnek azonban - a koncentráció elvét követve - négy tértípusra (az elmaradott, a depressziós, a rurális és a határmenti) kell összpontositania. E beavatkozási területeken él a Dél-Dunántúl népességének $41,7 \%$-a, 550 ezer fó.

\section{A fejlesztési stratégia kidolgozásának szervezeti rendszere}

A fejlesztési koncepció stratégiává formálásának eljárási rendje ma Magyarországon még nem kidolgozott. A készülỏ területfejlesztési törvény azonban - remélhetöleg tartalmazza majd a regionális stratégiaépítés legfontosabb teendöit. A területfejlesztés egyes szereplöinek meg kell határozniuk konkrét feladataikat és rögziteni célszerủ az együttmúködés alapelveit, annál is inkább, mivel a teruletfejlesztés sokszereplös és sokcsatornás finanszírozású tevékenység (tehát a partnerség és az addicionalitás gyakorlati alkalmazásához pontos szabályokra van szükség).

A regionális stratégiaépités legfontosabb munkaszakaszai az alábbi formát ölthetik:

1) A dél-dunántúli fejlesztési koncepció irányelveinek (amelyek nagyrészt illeszkednek a készüló Nemzeti Teruletfejlesztési Koncepció irányelveihez) figyelembevételével a megalakuló megyei teruletfejlesztési tanácsok - a kistérségek intézményes közremüködésével - összeállítják a megyei területfejlesztési stratégiákat; 
Faragó László - Horváth Gyula: A Dél-Dunántúl területfejlesztési koncepciójának alapelemei.

Tér és Társadalom, 9. 1995. 3-4. 47-77. p
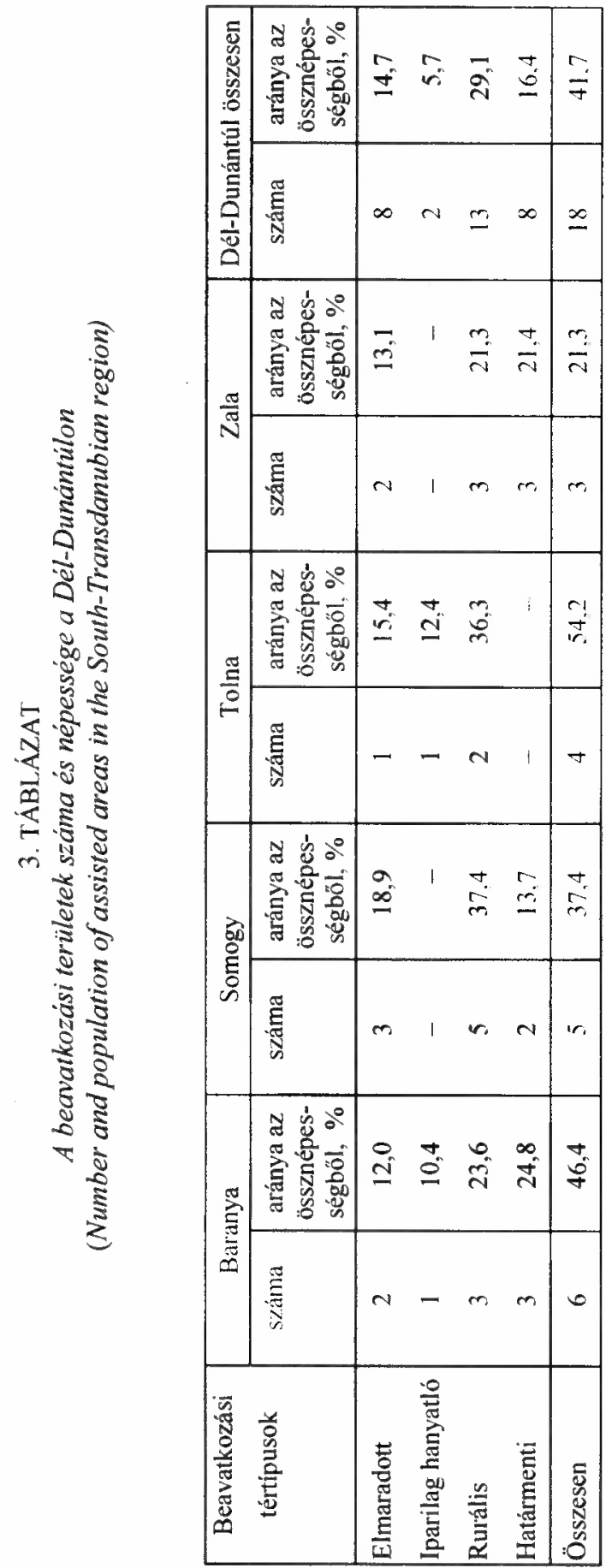

ช ש

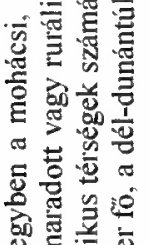

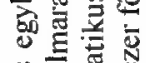

$\therefore$ 造

$\stackrel{2}{\approx} \frac{0}{0}$

른 范

\&

-

용

눈

되 $=8$

四

울

-

员:

D. .

n 1 曲

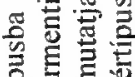

을

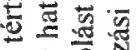

$\cong$ 융

흘

E

- $\frac{0}{2}-\overline{3}$

늘 它。

응 $\frac{1}{12}$

:

$1<$ 零

5 oi

ส

$x$ 告

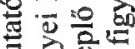

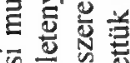

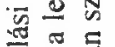

昰䨪

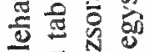

$\approx \widetilde{E}$

$\infty$ क्ष

记 焉

(ब)

थ

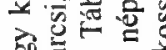

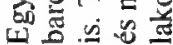


2) A megyei stratégiák - amelyek a dél-dunántúli fejlesztési koncepcióban jelzett programokat a megye belsó fejlődési szükségletei alapján konkrét projektekre bontják, illetve új programpontokat határoznak meg - a széles körü egyeztetési és jóváhagyási eljárás lefolytatása után indikativ (vagy kötelező érvényű) területfejlesztési dokumentummá válnak (tehát csak az abban szereplö fejlesztési alprogramok és akciók tarthatnak igényt a központi pénzalapok támogatásaira, illetve a területfejlesztés egyéb pénzügyi konstrukcióira). E legitimált programokat össze kell vetni a regionális fejlesztési koncepcióval és a szükséges korrekciókat követően a dél-dunántúli régió fejlesztési stratégiájának tervezete a kormány elé kerül, amely - a nemzeti területfejlesztési koncepció és az ágazati fejlesztési stratégiákkal egyeztetve - az Országos Területfejlesztési Tanács egyetértésével jóváhagyja azt. A stratégia jóváhagyását követően véglegesíthető a finanszírozási program. A Dél-Dunántúlnak az Európai Unió egységes programozási dokumentumához (Single Programming Document) hasonló stratégiai programja lehet. Ez a stratégiai dokumentum orientálhatja az ezredfordulóig a régió fejlesztéseit;

3) A fejlesztési stratégia programjai végrehajtásának kulcskérdése koordinációs mechanizmus müködtetése a közremüködő tucatnyi intézmény tevékenységének összehangolására. A régióban megtervezett fejlesztési feladatok - jellegük szerint - több koordinációs intézmény hatáskörébe tartoznak majd. Bár a területfejlesztési törvény valószinüleg nem teszi kötelezővé a regionális fejlesztési tanács létrehozását, a kérdés feletti döntést a megyei területfejlesztési tanácsok mérlegelésére bízza. A dél-dunántúli megyék elemi érdeke, hogy e szervezet mielöbb megalakuljon és hozzákezdjen a fejlesztési programok részletes kidolgozásához, a megyehatárokon átnyúló vagy a sajátos regionális adottságok miatt azonos megoldási módokat igénylö feladatok végrehajtásához. Hisz, mint láthatjuk, e közös teendők nagyobbik része átfogó koordinációt igényel (3. ábra). 
Faragó László - Horváth Gyula: A Dél-Dunántúl területfejlesztési koncepciójának alapelemei.

Tér és Társadalom, 9. 1995. 3-4. 47-77. p

TÉT $1995 \cdot 3-4$

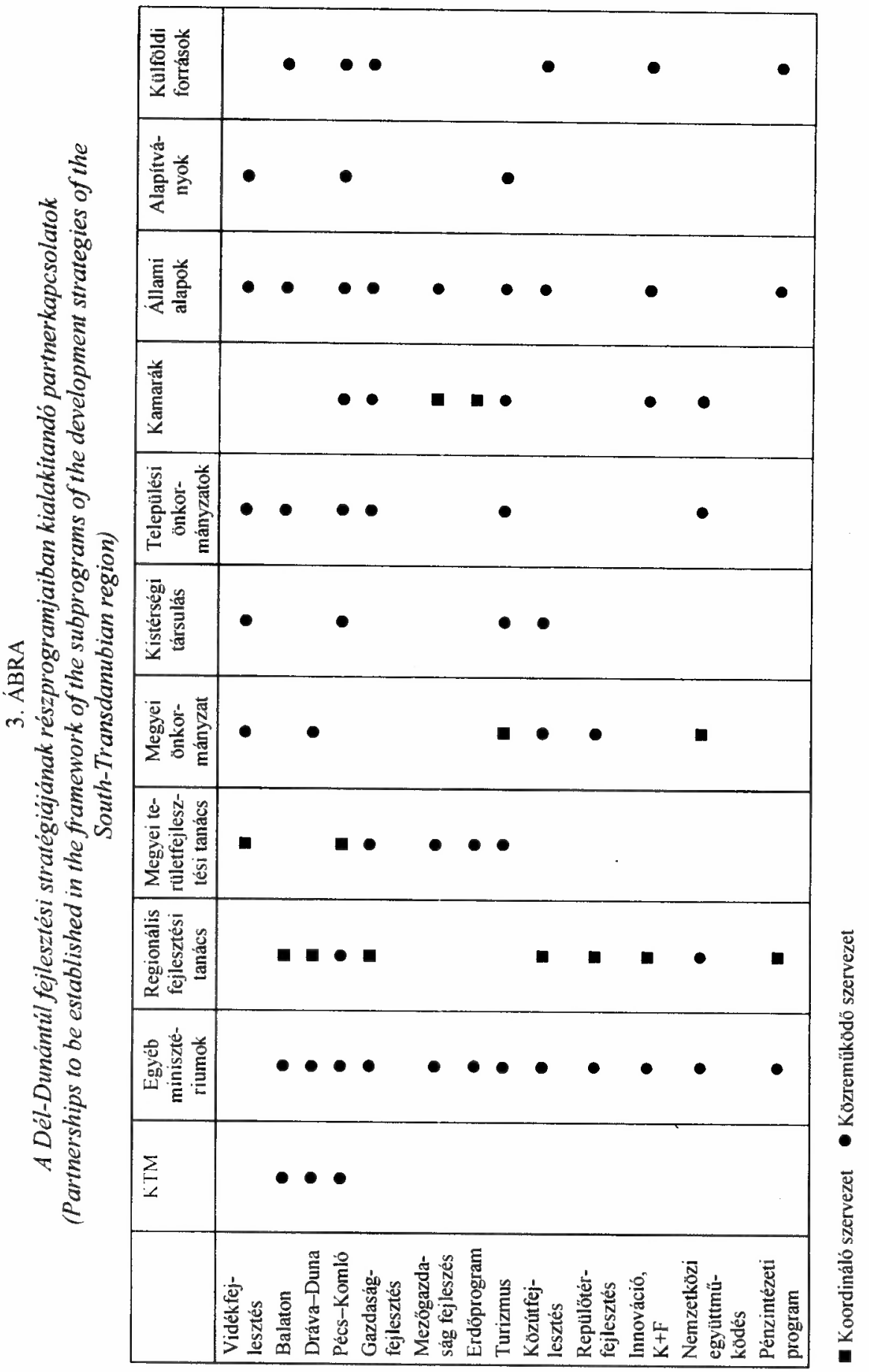




\section{ELEMENTS OF THE SOUTH TRANSDANUBIAN REGIONAL DEVELOPMENT CONCEPT}

\section{LÁSZLÓ FARAGÓ - GYULA HORVÁTH}

South Transdanubia is less developed and copes with more problems than the Middle and Northern part of Transdanubia. However, the crisis is not as extreme as in North East Hungary, and there is more hope for a better outcome than in regions in deeper crisis. Therefore, we need a comprehensive programme for the region. At the same time it is obvious that significant results cannot be achieved without co-operation based resolution and without the existence of suitable institutions and resources.

It was a promising sign in the planning and implementation of the programme that the various actors of the region did not expect development to be fostered by the sate only, but they themselves were eager to contribute. At the very beginning, many of these actors were drawn into the preparations of the programme. Also, the process of planning the concept proved quite significant in regard of regional integration a necessary element for development. Often, the process of planning also served as the framework within which interests were asserted.

A further sign anticipating the success of the programme was that several organisations of several types and levels contributed to the implementation with information, co-operation and also with financial resources.

Parallel to the completion of the concept, and because of the lack of a regional middle level, the South Transdanubian Foundation for Regional Development was established by the counties of Baranya, Somogy, Tolna and Zala. In the advisory board of this institution there are representatives of the government, but there are also representatives of the local governments, politicians, universities and the scientific and economic organisations of the region. These public funds may be the forerunner of the regional development board that has been recommended in the draft of the regional development bill now under negotiation.

On the basis of these promising signs, the government decided that South Transdanubia would be the next major region for which it would prepare a development concept. The regional development concept was included in the 1994 government programme. The new government did not reinforce this task as specifically labelled one. The Ministry of the Environment and Regional Development, which is responsible for this task, based upon preliminary inquiries and from its poor resources for planning, ordered from the Hungarian Academy of Sciences, Centre for Regional Studies the preparation of an economy and competition based development concept.

The paper summarises basic elements of the regional development concept, including priorities, programmes and institutional organisation of implementation. 